Please do not quote without checking with the authors.

\title{
Top Incomes in the Netherlands and the United Kingdom over the Twentieth Century ${ }^{1}$
}

A B Atkinson and Wiemer Salverda

$\begin{array}{ll}1 & \text { Introduction } \\ 2 & \text { Income Tax Data on Top Incomes in the UK and Netherlands } \\ 3 & \text { Methods } \\ 4 & \text { The Distribution of Top Incomes in the Netherlands and UK Compared } \\ 5 & \text { Conclusions }\end{array}$

Appendix A Sources of Tabulated Income Tax Data for the Netherlands

Appendix B Sources of Tabulated Income Tax Data for the UK

Appendix C Total Population and Income Data for the Netherlands

Appendix D Total Population and Income Data for the UK

\section{Introduction}

The recent rise in income inequality in the United States (US) and the United Kingdom (UK) has to be seen in both international and historical context. Rising income inequality in Anglo-Saxon countries has not necessarily been followed in other OECD countries. The Netherlands is of particular interest on this account, since it has seen an impressive growth of employment since the 1980s, and its unemployment rate has been closer to that of the US than to the EU average. It is natural to ask how far this employment policy has involved increased inequality in market incomes. The recent developments have moreover to be seen in the light of the longer-run evolution of the personal income distribution. For much of the first three-quarters of the twentieth century the dominant tendency had been for a decline in inequality. Tony Crosland wrote in his Future of Socialism that in Britain "the distribution of personal income has become significantly more equal" (1964, page 31). In an article written in 1979, Jan Pen summarised the experience of the Netherlands as "a clear case of levelling". It is interesting to ask how far changes in the 1980s and

1 We are most grateful to Cees Nierop for carrying out the calculations for the Dutch data and to Statistics Netherlands for making the data available. 
1990s have reversed the long-run tendency towards reduced inequality. How different was the end of the twentieth century from the beginning? The aim of this paper is to throw light on the differences across the two countries and across time at the top of the income distribution.

Taking a long-run and cross-country perspective on income distribution is important if we are to understand the underlying determinants, but implementing such an approach poses major problems in terms of data availability. In this paper we draw on one source that has been relatively under-utilised: the income tax returns. For the UK we use the published income tax tabulations; for the Netherlands we use the published tabulations for earlier years and the micro-data from tax records for more recent years. The income tax data are often regarded with considerable disbelief. There are indeed good grounds for doubting the income tax data. They are collected as part of an administrative process, which is not tailored to the needs of our analysis, so that the definitions of income, of income unit, etc are not those necessarily that we would have chosen. People not subject to taxation are omitted, and in the early days of income taxation they constituted a major part of the population. Those paying tax have a financial incentive to present their affairs in such a way that reduces tax liabilities. But these observations do not mean that the data are worthless. In that they measure with error the "true" variable in which we are interested, they are no different from other economic data. Moreover, they are the only source on which we can draw for much of the twentieth century. For these reasons, this source seems well worth further exploration.

The use of income tax data has indeed long historical roots. The work of Kuznets in the US on the Shares of Upper Income Groups in Income and Savings (1953) was based on the federal income tax returns. In the UK, Bowley (1914), Stamp (1916 and 1936), Champernowne (1936 and 1973), among others, studied the data resulting from the introduction of "super-tax" in 1908. In the Netherlands, Schultz (1968) and Hartog and Veenbergen (1978) (see also Hartog, 1983) constructed a long time series of income distribution estimates from 1914-1972 using the published income tax statistics. In Denmark, Sørensen (1993) made estimates using the Danish income tax data from 1870-1986. But, with these exceptions, income tax data have been little used in recent years. (See Morrisson, 2000, for a survey of historical data for Europe.) Fresh impetus has however been given by the work of Piketty (2000) on top incomes for France. Piketty utilised the income tax returns available from 1915 to calculate the shares in total gross income of top incomes. Together with Saez, he has constructed estimates for the United States that update, and modify, the work of Kuznets (Piketty and Saez, 2001). Atkinson (2002) has used super-tax and income tax data for the UK to construct top income series for the period 1908-1999. Saez and Veall (2003) have constructed estimates for Canada covering the period 1920-2000. 
The aim of this paper is to compare the development of the top part of the distribution of income over time in the Netherlands and the UK, two European countries with interesting similarities and interesting differences. Both are maritime nations; both have in their time been leaders of the world economy and then been overtaken. Both lost their colonies during the twentieth century; both experimented with incomes policies in the post-war period. They differ in scale (the UK population being about four times that of the Netherlands). The countries differ in their wartime experience. In Section 2, we describe the data for the UK, as used in Atkinson (2002) and for the Netherlands, building on the work of Schultz, Hartog and Veenbergen, but extending the series beyond 1972 using the Income Panel Survey micro-data from 1977. The methods applied in using the income tax data, and particularly the derivation of control totals for total population and total income, are set out in Section 3. In Section 4, we present the results for the share of top incomes in a way that emphasises the cross-country comparison, but which allows the reader to draw conclusions about the Netherlands and the UK separately. The results are summarised in Section 5.

\section{Income Tax Data on Top Incomes in the Netherlands and the UK}

Income tax data allow the possibility of comparing the long-run inequality patterns in different countries (see Kraus, 1981, for a valuable survey of data from this source). In this section, we describe the sources on gross and net incomes for the Netherlands (published income tax tabulations and the Income Panel Survey (IPO)) and those for the UK (published tabulations from the super-tax/surtax data and from the Survey of Personal Incomes (SPI) derived from income tax records). For further information about the Netherlands data, see Nierop and Salverda (2003), and about the UK data see Atkinson (2002).

\subsection{Income Tax Data for the Netherlands}

The income tax was introduced in the Netherlands on 1 May 1915, and the first data relate to the tax year 1915/16. We make use of the same sources as Hartog and Veenbergen (1978) see Appendix A. The distribution of taxable (gross) incomes was initially published in JaarCijfers voor het Koninkrijk der Nederlanden or (from 1925) Jaarcijfers voor Nederland (both referred to as JC), and then from 1931 in the annual Statistiek der Rijksfinanciën. In the latter source, the tabulations are very detailed; in some higher ranges the numbers of incomes are in single figures. The Centraal Bureau voor de Statistiek (CBS) in the 1930s published a less detailed distribution in a volume Statistiek der Inkomens en Vermogens in Nederland, containing distributional data classified by local communities. The data relate to tax units, combining the incomes of husbands and 
wives, and including the non-labour income of under-age children. The tables show the amounts of tax deducted, so that one can calculate the net of tax income for each range, but this is classified by the range of gross income.

According to the notes to the tables in early years, the assessment was based on income sources existing at 1 May of each year, but later the notes refer to income in the preceding year. According to JC 1937 (page 196) "in general the figures relate to the preceding year". The notes to JC 1943-1946, say (in English) "These figures relate in general to the incomes received in the calendar year preceding the fiscal year" (page 342). This indicates that the figures for, say, 1938/39 relate to the calendar year 1937. This is the procedure followed from 1915/16, taken to represent 1914, to 1940/41, taken to represent 1939. Corroborative evidence is provided by the footnote attached to the figure for 1938/39 (SR 1940, Table XVL, note 12) attributing the rise from 1937/38 to the effect of the devaluation of 28 September 1936. It also appears consistent with Hartog and Veenbergen (1978), who give pre-war figures for 1914 to 1939. It appears that the timing then changed with the introduction of a new income tax regime from 1 January 1941. Data for 1941 and 1946 are taken as relating to those years.

From 1950, the income tax data formed the basis for an official analysis of income distribution covering in principle the whole population, published as Inkomens- en Vermogensverdeling (IenV). Results are also published in the Statistical Yearbook (SY). As described, for example, in Inkomenverdelings 1959 en vermogensverdeling 1960, the estimates of the distribution are derived from tax forms (income and property tax) and are based on a sample for incomes below 30,000 guilders and property below 300,000 guilders, with complete coverage above these limits. The CBS, with access to the individual data, was able to carry out detailed analyses. Tabulations are given, for example, by "total income" (totaalinkomen), by "typical income" (kerninkomen), and by "spendable income" (besteedbaar inkomen). Total income is gross income, including benefits paid by the employer, minus expenses necessarily incurred in obtaining this income minus losses not already deducted, fiscal deductions (except those related to private houses) and certain personal obligations (but not pension contributions). Information on spendable income is available from 1959. Spendable income deducts income tax and social security contributions, interest paid and deductions for private houses (but excludes imputed rent on owner-occupied houses). The data are taken to refer to the year indicated: i.e. the Inkomensverdeling 1958 figures relate to 1958. This is again consistent with Hartog and Veenbergen (1978). ${ }^{2}$ The methods of analysis have varied over the years, with substantial changes being made in 1964, for which two

\footnotetext{
${ }^{2}$ Although they do not give a figure for 1941 (from JC 1947-1950, page 268).
} 
estimates are presented below, allowing a comparison to be made.

The unit of analysis up to 1979 is the tax unit, or "inkomenstrekker", as in the tax data. After 1979 the CBS analysis was carried out in terms of households, and the published tables provided less detail at the top, although a special analysis was made for 1980-1984 that gave the distribution by disposable income (de Kleijn and van de Stadt, 1987, page 12). For this reason, we have used micro-data from the Income Panel Survey for the period from 1977. In IPO imputed rent is included in disposable income. In 1979 the IenV data relate to full year incomes, so that there is in fact no overlap (the IenV series for total income ending in 1975).

\section{The Income Panel Survey (IPO)}

The IPO data are described in Nierop and Salverda (2003). The main source is the annual income tax files, which are combined with other public administrative sources such as those covering rent subsidies, student grants and child allowances. The survey is a random sample of the population aged 15 and over, and comprises information on personal income that is combined to form household incomes. The number of cases is around 200,000; they are reweighted to make the survey nationally representative in terms of household characteristics.

\section{Changes in Tax Legislation and Statistical Presentation}

The tax legislation affects the comparability of the figures both with the UK and internally across time in the Netherlands. Hartog and Veenbergen describe three fiscal regimes: the 1914 Act, the1941 Act and 1964 Act. As they note, the 1914 legislation was in effect for a long period, allowing continuity in data collection. The 1941 Act changed, among other aspects, the treatment of 'new sources' of income. Under the initial legislation, existing sources of income were taxed on the basis of income in the preceding year, but a prediction was made of the income from new sources. After 1941 only past income was included.

The tax treatment of households evolved as follows (cf. Pott-Buter and Tijdens, 2002). From the start in 1914 to 1972 the basic principle was to take the incomes of married persons together and tax them as one income, although some changes were made to the way they were added together, initially (1941) to influence the level of taxation between couples and singles and later (1962) to also stimulate the employment participation of women. From 1973 on, the income from labour of married women was taxed individually (from 1976 extended to disability benefit) while all other types of income and tax deductions not related to labour still had to be declared by the man or, later, the highest earner in the household. This principle has remained unchanged until the 
major revision of the tax system in 2001 - introduced just after the end of the period covered here. Since then several other types of income and deductions can be split between the two partners as they wish for optimising their tax contribution. During the period 1973-2000, several important changes were made to the practice of applying the principle with important effects, on the one hand, on female (part-time) employment participation - which outside the scope of this contribution - and, on the other hand, also on the demarcation of the household. Under certain conditions, people living together without formal marriage can opt for 'fiscal partnership' and be treated on the same basis as married couples. The financial structure of the tax system can encourage this. The quantitative importance of this partnership is unknown.

In the statistical treatment there were changes in the treatment of part-year incomes in 1964. Whereas income had previously been converted to an annual equivalent, the 'assessment to time proportion' was introduced (Statistical Yearbook of the Netherlands 1971, page 283). This affected the statistics. Subsequently, tax units were allocated to intervals on the basis of their annual income but only actual income was added to the amounts. There is therefore a noticeable break in the series in 1964 and two estimates are given for that year.

\section{Netherlands Data:A Summary}

The main components of the Dutch data for the distribution of income (total and disposable) by tax units may be summarised as follows:

1914-1946: from tabulated income tax data, published in JC and Statistiek der Rijksfinanciën; information on gross income (and net income by range of gross income), with break in continuity in 1941;

1950-1975: from tabulated data in IenV with break in continuity in 1964; information on gross income (and spendable income from 1959);

1977-1999: information on gross income and spendable income from IPO micro-data.

We have therefore a three-part series, in contrast to the unified series for France constructed by Piketty (2000) and the Anglo-Saxon series. As however will become clear in the next section, the series for the UK is also marked by two breaks.

\subsection{Income Tax Data for the UK}

The income tax began much earlier in the UK (in 1799) but the data are in fact less rich, since its form of administration for much of the subsequent period was not well suited to the purpose 
of measuring the distribution of the total income of taxpaying units. The basic problem lay in the schedular system. With different income tax schedules covering different sources of income, the authorities did not know the total income of individuals, which could be the subject of several separate assessments. The first British income tax, Pitt's Act of 1799, did require an assessment of total income (and there are data for 1801), but the schedular system, and deduction of tax at source for certain classes of income, were adopted when the income tax was re-introduced by Addington in 1803.

In these circumstances, a particular importance attaches to the introduction in 1909 of "super-tax", which was an additional income tax levied on the total incomes of the very rich. This provided information on total incomes that had not previously been available on a regular basis. More precisely, we have annual tabulations, by range of total income as measured for tax purposes (i.e. gross income), of the number of "persons" and "total income assessed", covering tax years (see Appendix B for a list of the sources). The super-tax information has shortcomings and covers only a small fraction of the population, but it provides a source of evidence about the distribution of top incomes for every year. Super-tax was renamed "surtax" in 1927. The basic source of information are the Annual Reports of the Inland Revenue, they are referred to below as AR.

The super-tax/surtax data are valuable but they are limited to the very top of the distribution and came to an end in 1973/4 when income tax and surtax were merged into a single unified income tax. Statistics for the whole income-tax paying population comparable with those published in the Dutch Statistiek der Rijksfinanciën are only available when the Inland Revenue assembled information from different schedules to arrive at estimates of total income for individual taxpayers. Such a special investigation was first conducted for incomes assessed for the income tax year 19189, repeated for 1919-20 and 1937-8, taken as referring to incomes in the calendar years 1918, 1919 and 1937, respectively, although this timing is only approximate. ${ }^{3}$ Out of this grew the Survey of Personal Incomes (SPI), when the Inland Revenue began a series of quinquennial inquiries (194950, 1954-5, 1959-60, 1964-5, and 1969-79) based on the information contained in the income tax records for a sample of taxpayers. ${ }^{4}$ From 1963-4 this was supplemented by smaller annual surveys with a sample size of around 125,000, and these continue to the present day. The advantages and disadvantages of this source are well described in the 1979-80 survey: “The Survey of Personal

3 The timing is complicated by the fact that different types of income are assessed at different dates. Income returned for the tax year 1937-8 in part relates to income accruing in that year (for example the income of weekly wage-earners assessed half-yearly) and in part to income in the year 1936-7 (see AR 1939-40, page 29 and Barna, 1945, page 254).

${ }^{4}$ The figures from the Inland Revenue special enquiries are referred to below as the SPI distributions 
Incomes is the largest regular survey conducted in the field of personal incomes and, being based on administrative records rather than household enquiries, it benefits from a high response rate and complete objectivity. On the other hand, it does suffer certain drawbacks, notably in coverage, both of the population and of income. Out of a total population of "tax units" of about 29 million in 197980 , the income survey fully covered about 23 million - nearly 80 per cent - the remaining 20 per cent consisting mainly of the elderly people whose incomes were not high enough to be taxable. The coverage of income in the survey extends only to income subject to tax; income excluded from tax such as certain social security benefits (principally sickness, unemployment and supplementary benefits and, since 1977-78, child benefit) is excluded." (Inland Revenue, 1983, page 8).

The 1918 and 1919 UK statistics show the tax deducted, so that we have the distribution of net of tax income but by range of gross income. The distribution by net of tax income is first available for 1937. (See Appendix B for a list of the sources.) It should be noted that this definition differs from that of disposable income in the Netherlands, in that social security contributions are not deducted in the UK after tax distribution. The SPI distributions have been used by the Central Statistical Office to arrive at estimates of the distribution of income, referred to as the "Blue Book" estimates, as they were published for many years in the national income Blue Books.

Together, these sources cover virtually the whole of the twentieth century. Where they overlap, we take the SPI estimates, as they cover a larger fraction of the population, and give information by range of net income. Even though there are certain differences, the resulting figures are very close for the income groups that are common to the two sources, and they are treated as equivalent. The SPI results are based on tabulations published regularly in the Annual Reports of the Inland Revenue, or later in Inland Revenue Statistics (see Appendix B). Micro-data are available from the Data Archive at the University of Essex for only a small number of years (1985-86, 199596, 1996-97 and 1997-98) and have not been used.

\section{Changes in Tax Legislation and Two Structural Statistical Breaks}

The tax law has changed frequently over the period 1908-1999. Legislation has in some cases extended the tax base (for instance, surtax directions for close companies, and inclusion of short-term capital gains) and in others narrowed the base (for example, cessation of the taxation of imputed rents on owner-occupied houses and the replacement of taxable family allowances by taxfree child benefit). There have been changes in the compass of the tax unit, including the aggregation, and then disaggregation, of a child's investment income with that of the parents. There have also, as 
we have already seen, been major changes in the way tax statistics are collected and published.

Of potential significance here are two changes. The first is in the form of tax statistics. From 1975-6, the figures relate to total income. Prior to the SPI 1976-6, the distribution relates to total net income, which differs from total income in that it deducts (i) allowable interest payments such as those for house purchase, (ii) alimony and maintenance payments, (iii) retirement annuity premiums, and (iv) other allowable annual payments. The use of the term "net" is potentially confusing, since it here relates, not to after-tax income, but to income before tax but after deduction of allowable outgoings. In 1975-6, the difference was $£ 2.4$ billion, or some $3 \%$ of total income. The Central Statistical Office (1978) analysed the distributional consequences of the change in definition in 1975-6 showing that it particularly affected the highest percentile, which increased by $5.6 \%$. The effect on top shares was however relatively modest: the share of the top $1 \%$ was shown as rising from 5.6 to $5.7 \%$, and that of the top $10 \%$ from $25.8 \%$ to $26.2 \%$.

The second structural break came in 1990 when independent taxation was introduced for husbands and wives. Until 1990, the incomes of husband and wife were aggregated in the SPI data (this applied even where there had been election for separate taxation). Atkinson and Harrison (1978, Chapter 9) consider the comparison of distributions with different definitions of the tax unit. If we treat all units as weighted equally (so couples do not count twice) and take total income, then the impact of moving from a couple-based to an individual-based system depends on the joint distribution of income. A useful special case is that where the marginal distributions are such that the upper tail is Pareto in form with exponent a. Suppose first that all rich people are either unmarried or have partners with zero income. The number of individuals with incomes in excess of $£ X$ is the same as the number of units and their total income is the same. The overall total of income is unchanged, but the number of individuals exceeds the number of tax units (by a factor written as $(1+m)$ ). This means that to locate the top $i \%$, we now need to go further down the distribution, and, given, the Pareto assumption, the share rises by a factor $(1+\mathrm{m})^{1-1 / \mathrm{a}}$. With $\mathrm{a}=2$ and $\mathrm{m}=0.4$, this equals 1.18 . On the other hand, if all rich tax units consist of couples with equal incomes, then the same amount (and share) of total income is received by $2 /(1+\mathrm{m})$ times the fraction of the population. In the case of the Pareto distribution, this means that the share of the top $1 \%$ is reduced by a factor $(2 /(1+\mathrm{m}))^{1-1 / a}$. With $\mathrm{a}=2$ and $\mathrm{m}=0.4$, this equals 1.2 . We have therefore likely bounds on the effect of moving to an individual basis. If the share of the top $1 \%$ is $8 \%$, then this could be increased to $9.4 \%$ or reduced to $6.7 \%$. This second structural break is therefore potentially more significant. 


\section{UK Data: A Summary}

The main components of the UK data for the distribution of income (total and disposable) by tax units are therefore:

Tabulated data from SPI data for 1918, 1919, 1937, 1949, 1954, 1959, 1962-1999 (except 1980 where data missing) covering distribution by gross and, from 1937, by net of tax income, with structural breaks in 1975-6 (minor) and 1990-1 (major);

Tabulated data from super-tax/surtax returns for all years from 1908 to 1972 covering distribution by gross incomes.

The main features of the super-tax/surtax/SPI data are summarised in Table 1, with for comparison the equivalent information for the Dutch tabulated data in Statistiek der Rijksfinanciën (SR) and in Inkomens- en Vermogensverdeling (IenV). The years of coverage for the two countries and for the two income concepts are illustrated in Figure 1. 
Table 1 Comparison of Income Tax Data Sources

\begin{tabular}{|c|c|c|}
\hline Data & UK & Netherlands \\
\hline $\begin{array}{l}\text { Geographical } \\
\text { coverage }\end{array}$ & $\begin{array}{l}\text { United Kingdom, which prior to } 1921 \text { includes what is } \\
\text { now the Irish Republic; does not include colonies. }\end{array}$ & $\begin{array}{l}\text { Kingdom of the Netherlands; does not include } \\
\text { colonies. }\end{array}$ \\
\hline $\begin{array}{l}\text { Definition of } \\
\text { income }\end{array}$ & $\begin{array}{l}\text { Total gross income (net of allowable deductions until } \\
1975-6 \text { ) and total net of tax income. }\end{array}$ & Total gross income and total disposable income. \\
\hline Timing & $\begin{array}{l}\text { Income computed for tax year (ending } 5 \text { April in year } \\
\mathrm{T} \text { ); to allow for lags, taken as income accruing in } \\
\text { calendar year } \mathrm{T}-1 \text {; supertax years renumbered to allow } \\
\text { for fact that tax assessed in year } \mathrm{T}+1 \text {. }\end{array}$ & see text \\
\hline $\begin{array}{l}\text { Number of } \\
\text { ranges }\end{array}$ & $\begin{array}{l}11 \text { ranges in original supertax data, increasing to } 17 \\
\text { ranges in later years }\end{array}$ & $\begin{array}{l}\text { In tax data varies over years from } 9(1922) \text { to } 34 \\
\text { (1928); in IenV around } 30 \text { (e.g. } 32 \text { in 1958) }\end{array}$ \\
\hline $\begin{array}{l}\text { Limit on } \\
\text { numbers in cell }\end{array}$ & No limit, lowest number 37 taxpayers & $\begin{array}{l}\text { No limit in income tax tabulations, lowest positive } \\
\text { number } 1 \text { taxpayer }\end{array}$ \\
\hline $\begin{array}{l}\text { Information on } \\
\text { tax unit } \\
\text { composition }\end{array}$ & $\begin{array}{l}\text { No information in supertax returns; surtax data from } \\
1965 \text { show married/single; SPI from } 1937 \text { has family } \\
\text { composition. }\end{array}$ & $\begin{array}{l}\text { Distribution classified by married/single from } 1930 \text {. } \\
\text { The IPO surveys present more detail such as age and } \\
\text { other members of the household except the couple. }\end{array}$ \\
\hline $\begin{array}{l}\text { Information on } \\
\text { net incomes }\end{array}$ & $\begin{array}{l}\text { Distribution of net of tax income by range of net of tax } \\
\text { income available in SPI from 1937-8; distribution of } \\
\text { net of tax income by range of gross income available } \\
\text { in SPI from 1918. }\end{array}$ & $\begin{array}{l}\text { Distribution of spendable income available from } \\
\text { 1959; distribution of net of tax income by range of } \\
\text { gross income available from } 1914 \text {. }\end{array}$ \\
\hline
\end{tabular}




\section{Methods}

The use of the income tax data to study the distribution of income raises a number of methodological problems. In assessing the evidence, we apply both an absolute standard, considering the deficiencies of the data compared with a theoretical ideal, and a comparative standard, asking how far the series for the two countries may be regarded as comparable. Tax avoidance for example may cause the shares of top income groups to be understated, but it may do so to a similar extent in the two countries. In the same way, when we are seeking comparability over time, a constant level of tax avoidance may not affect the conclusions regarding changes over time. Put differently, there is a tension between achieving the best estimate at a point in time, and maintaining consistency across countries and across time. This tension is familiar to national income statisticians, where improvements in present day measures may cause problems for the calculation of growth rates or for the comparison of GDP across countries. As will be evident below, our approach involves compromises between what would be the best measure of the income distribution at a point in time and the desire the compare with quite distant periods in the past (the beginning of the twentieth century) and across the Netherlands and the UK.

The basic limitation is that, for many years, the tax data give only partial coverage of the population. Here we follow two approaches, which we can associate with Kuznets and with Pareto.

The approach of Kuznets (1953) was to compare the income tax data with countrywide estimates of the total population and of the total income. In the case of the UK in 1908 this means that we take the 11,328 tax units in 1908 and express them as a percentage $(0.05 \%)$ of the estimated total number of tax units. Similarly we take their total income of $£ 139.6$ million and express it as a percentage of estimated total income, which gives $8.8 \%$. The key issue here is then the derivation of the control totals for total tax units and total income. These reference totals are discussed below.

The second method focuses on the distribution within the top group. If we have a control total for population, we can calculate for example the share of the top $1 \%$ within the top $10 \%$. This gives a measure of the degree of inequality among the top incomes. Such an approach has been long used: see Macgregor (1936), who noted that it made a bridge between Pareto and Lorenz. Suppose again that the upper tail of the distribution approaches the Pareto form: i.e. that the cumulative distribution $\mathrm{F}$ is such that $(1-\mathrm{F})$ is proportional to $\mathrm{y}^{-\mathrm{a}}$, where $\mathrm{y}$ is income. If we assume 
that this holds exactly within the top income group, then this implies that the share of the top 1 percent within the top 10 percent is $(0.1)^{(1-1 / a)}$. The same value would be obtained if we took the share of the top $0.1 \%$ in the top $1 \%$. By taking the share within the taxpaying population, we do not need to estimate the total income, although we still need a total for the population. It should be noted that where the distribution is not exactly Pareto, this method would yield a different value for the Pareto coefficient a from that reached, for example, by using the cut-off value of income as well as the cumulative frequency distribution and the cumulative total income. (Put differently, the implied slope of the Lorenz curve may not equal the cut-off value of income.) Moreover, it uses information on all ranges above (via the cumulative income share), in contrast to methods of calculating the Pareto exponent that use adjacent points on the cumulative distribution. For this reason, we shall refer to it as the Pareto-Lorenz coefficient, since it is the Pareto coefficient derived from the Lorenz curve without resort to the income cut-off level.

\subsection{Control Totals for Population}

The control total we are seeking is that for the total of tax units in the population. It should be stressed that the total number of tax units should not be confused with the total number of actual taxpayers, which may be considerably smaller. In the Netherlands in 1935 for example there were 1.3 million taxpaying units, whereas our estimated control total is some 4 million.

Our starting points in both countries is to take the total population aged $15+$ at a specified date and subtract the number of married females or, in the Netherlands, the number of married men where this is smaller. (See Appendices C and D for the details.) This "constructed total" would be a correct control total for tax units if all children under the age of 15 were dependent and all children aged 15+ formed separate tax units. This total is then compared with official estimates available for certain years. In the UK, the Blue Book estimates prepared by the Central Statistical Office provide a benchmark, and the control total is adjusted to the same basis - see Atkinson, 2002, Appendix A for details and for the final numbers of tax units. The total for tax units is typically less than the constructed total. Among the reasons for the difference is that the number of children under the age of 15 with their own income (for example from investments) is smaller than the number of children aged 15+ who have no independent income. From 1990, when independent taxation was introduced for husbands and wives, the UK figure is based on the total number of persons aged 15+ (this differs from Atkinson, 2002).

In the case of the Netherlands, we show in Table $\mathrm{C} 1$ the constructed total and the number of income units recorded in the IenV and the IPO estimates. While in the early years there was 
recognised to be a substantial shortfall in the IenV, the total converged over time towards the constructed total. By 1999 the IPO total was fairly stable at around 95\% of the constructed total, and the coverage was believed to be complete. We have therefore taken the IPO totals when presenting these estimates, and a fixed proportion (95\%) of the constructed total for all earlier years - see Appendix C.

It should be noted that this approach does not allow for the existence in the tax data of partyear incomes. Part-year units may arise for several reasons. People reach the age of 15 in the course of the tax year; people die in the tax year; women marry in the course of the tax year and cease to be separate units; people may emigrate or immigrate. Official studies using the tax data often make corrections for such units. The IenV studies in a number of years converted part-year incomes into annual equivalents. ${ }^{5}$ In the UK, the problem of 'part-year units' was examined by the Royal Commission on the Distribution of Income and Wealth (1979, page 36). Adjustments to the distribution of before tax income indicated that in 1975/6 the exclusion of such units would have reduced the Gini coefficient from $37.3 \%$ to $34.7 \%$, but would have had a much smaller impact on the upper income groups, reducing the share of the top $10 \%$ by 0.3 percentage points.

\subsection{Control Totals for Total Income}

In considering the definition of income, it may be helpful to work back from total personal income as recorded in national accounts. The national accounts total for personal income is important in view of the fact that the national accounts are a valuable historical benchmark and a link across countries via the United Nations System of National Accounts (SNA). The different stages are set out schematically below:

Personal sector total income

- $\quad$ Non-Household income (e.g. charities)

$=\quad$ Household sector total income $(\mathrm{H})$

- $\quad$ Items not included in preferred definition of income (e.g. employers' social security contributions)

$=\quad$ Preferred Household Income Definition $(\mathrm{P})$

- $\quad$ Items not included in tax base (e.g. certain social security benefits)

\footnotetext{
${ }^{5}$ This may be done in at least two ways: we could treat a person present with an income of $\mathrm{Y}$ for
} half the year as 1 person with income $2 \mathrm{Y}$ or as half a person with income $\mathrm{Y}$. 
- $\quad$ Taxable Income of those not included in tax statistics ("non-filers")

$=\quad$ Tax Statistics Income $(\mathrm{S})$

The first adjustment is to eliminate non-household elements. The personal sector is more extensive than households and unincorporated businesses: it includes in the UK for example, life assurance and pension funds, and private non-profit-making bodies serving persons (such as universities, charities, churches, trade unions). The second adjustment arises because the definition of income "preferred" in typical distributional analyses by central statistical offices differs from that adopted in the national accounts. ${ }^{6}$ For example, imputed rent on owner-occupied housing features in national accounts estimates but is usually not included in distributional studies. Here and elsewhere the differences work in both directions, so that the minus sign may in fact be in front of a negative quantity. The tax base does not of course necessarily correspond to this preferred definition. Typical tax laws do not allow full deduction of all interest paid; on the other hand, social security payments may not be taxable. The taxable income may refer to an earlier time period (which is why national account figures may include a reference period adjustment). The recorded taxable income may, moreover, differ from the true value on account of understatement. Finally, as already stressed, there are people not included ("non-filers").

The income tax statistics in the Netherlands have been more extensive in their coverage of the population than those in the UK for most of the period. The IenV estimates are described by the CBS as giving since 1975 "an almost complete picture", and for the IPO estimates from 1977 we take the totals as reported. For the pre-Second World War period, the Netherlands statistical office has made estimates of the income of non-filers, and these have been used directly. We are following here Hartog and Veenbergen (1978). For the interim period (1946-1975), we allocate to each nonfiling tax unit a percentage of the mean income of filers, a method used by Piketty and Saez (2001) in the US.

In the UK, the CSO has made estimates of total "allocated" income as the basis for its estimates of the distribution of income. The methods are described in detail by Ramprakash (1975) and Stark (1972 and 1978). In Atkinson (2002), this was used as the basis for the estimated distributions. Such a basis does however correspond to definition P in the typology above, rather

\footnotetext{
${ }^{6}$ The theoretical relation between the definition of income in the national accounts and the control total for income appropriate for income distribution analysis has been examined in detail by the
} 
than the definition $\mathrm{T}$ reached by adding to tax statistics income the income of non-filers. In what follows (see Appendix D for more details) we have taken as a basis estimates of the total "taxable pensions and employment income that are missed from the SPI because they are not of sufficient size to be taxed" (Ramprakash, 1975, page 78). For 1972/73, this increased the SPI total of $£ 40,778$ million to $£ 43,316$ million, which is less than the allocated total of $£ 45,764$ million. These estimates only exist for a small number of years, and for much of the period considerable additional estimation is necessary (see Appendix D). For the period since 1945 the most important missing elements have been pension income, from state and private sources, and the evidence suggests that non-filing of employment income is sufficiently small to be ignored. For the period prior to 1945 , when the proportion of filers was much smaller, it has been necessary to make estimates of the wages not assessed, of salaries and self-employment income below the exemption level, of dividends below the exemption level and of contributory pensions. In making these new estimates of total taxable income, considerable use has been made of the earlier work of Bowley and Stamp (1927), Clark (1937), Bowley (1937), Barna (1945), and Feinstein (1972). The resulting totals are shown in Tables D1 and D2 in Appendix D. It should be emphasised that they are surrounded with considerable uncertainty and that certain periods are better covered by the necessary ingredient series and by contemporary estimates providing points of reference. The war periods and the years immediately following the First World War are particularly subject to error. Feinstein (1972) gives a grading of B ("good") to many of the underlying national accounts series, indicating an error of $\pm(5 \%-15 \%)$. For the war years and 1918-1920 the upper end of this possible range seems appropriate; for other years $\pm 5 \%$ may be a reasonable guide.

\subsection{Gross and Disposable Income Distributions}

We are interested both in gross and disposable income distributions, in the sense that the former embodies the implications of the market economy for individuals and that the latter represents disposable resources. The definition of these concepts does however raise a number of issues. As already noted, the term "net" is used in different ways. Here we take the term as applying to the distribution of income after tax, but this can mean after deducting income tax (as in the UK case) or after deducting income tax and social security contributions, or after deducting all direct taxes. The treatment of social security contributions poses particular problems. Should we deduct the whole contributions paid, or only that part which does not correspond to current or future services? Should any distinction be drawn between public and private schemes? Is it logical to treat employee 
contributions differently from those made by employers?

Here we adopt a pragmatic approach. In the case of the UK, we use "net of tax income" as described above. The control total is that described above less the total income tax paid. In the Netherlands, we use the official estimates of the distribution of spendable income which are available from 1959. Spendable income deducts income tax and social security contributions, interest paid and deductions for private houses (but excludes imputed rent on owner-occupied houses). The differences between these two concepts needs to be borne in mind in what follows.

There is also information, not used here, in earlier years in both countries referring to the distribution of net of tax income classified by range of gross income. A calculation of the share of the top $\mathrm{i} \%$ in total net of tax income from this classification will provide an under-estimate, since the re-ranking to classify by net of tax income can only increase the measured share.

\subsection{Interpolation}

Where the basic data on which we are drawing are in the form of grouped tabulations, then, since the intervals do not in general coincide with the percentage groups of the population with which we are concerned (such as the top $0.1 \%$ ), we have to interpolate in order to arrive at values for summary statistics such as the percentiles and shares of total income. The distributions typically show the number of tax units, and the total amount of income, in each of a number of specified ranges of income (e.g. 1000 to 1500 guilders), with an open-ended top interval. The standard practice, adopted by Feenberg and Poterba (1993 and 2000) and Piketty (2000), is to assume that the distribution is Pareto in form. This method has however the problem that, as noted earlier, the information described above allows us to obtain more than one value for the exponent of the Pareto distribution, and hence different interpolated values. An alternative approach is based on placing upper and lower bounds. Gross upper and lower bounds on the Lorenz curve can be obtained by joining the observed points linearly or by forming the envelope of lines drawn through the observed points with slopes equal to the interval endpoints divided by the mean (see Cowell, 1995, page 114). Where there are detailed ranges, as in much of the early Dutch data, the results for the lower bound (linearised Lorenz curve) are normally very close to the upper bound (indistinguishable on the graphs drawn), but in other cases the differences can be more marked, depending on where the ranges fall in relation to the shares in which we are interested. In the tables we show in italics estimates cases where there are noticeable differences between the lower and upper bounds. ${ }^{7}$ In

\footnotetext{
${ }^{7}$ The following rule of thumb was adopted. The difference was treated as "noticeable" where it exceeded 0.25 for shares less than $5 \%, 0.5$ for shares between 5 and 10\%, 1.0 for shares between 
order to give a single estimate, we have used the mean-split histogram. The rationale is as follows. Assuming, as seems reasonable in the case of top incomes, that the frequency distribution is nondecreasing, then tighter, restricted bounds can be calculated (Gastwirth, 1972). These bounds are limiting forms of the split histogram, with one of the two densities tending to zero or infinity - see Atkinson (2002, Appendix C). Guaranteed to lie between these is the histogram split at the interval mean with sections of positive density on either side. ${ }^{8}$

\section{The Distribution of Top Incomes in the Netherlands and UK Compared}

In this section, we summarise the main findings for the two countries. Tables $2 \mathrm{NL}$ and $2 \mathrm{UK}$, and Figures $2 \mathrm{~A}$ and $2 \mathrm{~B}$, summarise the results for the percentile shares covering the following groups: top $10 \%$, top $5 \%$, top $1 \%, 0.5 \%$, and $0.1 \%$. In the case of the Netherlands, two explicit breaks are shown. For 1964, we can compare the two estimates, and the differences appear small: $0.44 \%$ for the share of the top $10 \%$, which was some $34 \%$. This "break" is not therefore signalled in Figures $2 \mathrm{~A}$ and $2 \mathrm{~B}$. The switch from the IenV to IPO estimates does not allow any overlap year, but the first IPO figures, for 1977, are mostly closer to the IenV figures for 1975 than the latter are to the IenV figures for 1973. For the UK, we have shown in Table 2UK three breaks: the independence of Southern Ireland in 1920, the change in definitions in 1974, and the switch to independent taxation in 1990. Only the latter seems material.

In the case of the Netherlands, we can compare our estimates for the top $10 \%$ with those of Hartog and Veenbergen (1978, Table 1). Their estimates cover the period 1914 to 1972. 'At the end of the period, the estimates are very close (less than half a percentage point). Initially our estimates are about 3.5 percentage points higher, with the difference declining between 1939 and 1950 to around 2 percentage points and then narrowing. On this basis, we show a modestly larger fall in the share of the top $10 \%$ over the period as a whole. Hartog and Veenbergen did not disaggregate the top $10 \%$, but they show (Table 2) the percentage of income recipients per income decile. For 1914 they show $1 \%$ of tax units receiving $20 \%$ of total income, which is very close to our figure; for 1972 they show $1 \%$ receiving $10 \%$ of total income, which is again very close to our figure.

When we compare the two countries, what is the broad picture? For the first three-quarters

10 and 20\%, 2.0 for shares between 20 and $30 \%$, and 3.0 for shares above $30 \%$.

${ }^{8}$ We show by shading the (very small) number of cases where the mean for the relevant range exceeded the midpoint, thus contradicting the non-increasing density assumption. 
of the century, the share of top income groups fell sharply in both countries. The top $1 \%$ began with some $20 \%$ of total gross income, but by 1977 this share had fallen to about $6 \%$. The share of the top $0.1 \%$ fell from around $10 \%$ to around $1 \%$. The rate of fall was similar in both countries, and even the annual movements mirror each other to a remarkable degree. Comparing the two countries, we see that the shares for the Netherlands (indicated by hollow diamonds) tended to be initially rather higher for the top $10 \%$ and $5 \%$, with a smaller difference for the top $1 \%$ and smaller groups, although it should be noted that the UK data is very limited at this time. It also appears that the fall in the 1950s and 1960s was less in the Netherlands, but sharper in the 1970s, so that 1977 saw a remarkable degree of agreement:

$\begin{array}{llllll} & 10 \% & 5 \% & 1 \% & 0.5 \% & 0.1 \% \\ \text { NL } & 26.85 & 16.76 & 5.82 & 3.69 & 1.22 \\ \text { UK } & 27.96 & 17.33 & 5.93 & 3.75 & 1.27\end{array}$

This makes all the more interesting the subsequent difference. From 1977 to 1999 the IPO-based estimates in the Netherlands showed only a modest, 1 percentage point, rise in the share of the top 10\%, whereas in the UK, the rise from 1977 to1989 was 6.3 percentage points, and the rise from 1990 to 1999 was 3.6 percentage points. Even allowing for the break with the introduction of independent taxation, the rise was 10 percentage points. For the top $1 \%$, the UK rise, calculated in the same way, was 5.9 percentage points, whereas in the Netherlands the share of the top $1 \%$ fell between 1977 and 1999 slightly, from 5.8 to 5.4 per cent.

Changes in the shares of top income groups can come about in part because of redistribution between them and the rest of the population and in part on account of alterations in the distribution within the top income groups. The within-distribution is shown in Figure 3A. We should note again that these "shares within shares" do not depend on the control totals for income; they are therefore not affected by any differences across countries in the derivation of these totals. Not only are the movements for the two groups very similar within the two countries, but also they are similar across countries until 1977. After 1977 the within-shares rise sharply in the UK, but not in the Netherlands. It is interesting to compare the shares of the richest $10 \%$ within the top groups with the overall share of the top $10 \%$. In the Netherlands, the overall share began at a very similar value, but fell less in the 1920s and again in the 1970s, periods when there was sharper redistribution within the top income group. This appears even more marked in the UK (although we have only limited evidence prior to 1949), where the within-redistribution was marked in the 1970s. Since 1977 the redistribution towards the top $10 \%$ away from the rest of the population has proceeded in parallel with redistribution within the top $10 \%$. This latter element is captured in the Pareto coefficients 
shown in Figure 3B, which have fallen in the UK from around 3 in 1977 to around 2 in 1999. This is a dramatic fall, whereas the coefficient in the Netherlands has continued to rise.

\section{Distribution after Tax}

Evidence about the distribution after tax is more limited, and the concepts of income differ in the two countries. There is also more than one series for the Netherlands. The IenV series for disposable incomes shown in Figures 4A and 4B relates only to full-year incomes (from SEM, 1987). For the period since 1959, when the Dutch series begins, the decline for that country is rather larger, leading to 1977 figures that are close to the British. Post-1977 the two countries again diverge. The Netherlands data show very little change in the shares of top income groups in disposable income. In the UK the share of the top $1 \%$ rises from $4.2 \%$ in 1977 to $7.1 \%$ in 1989 , and a further 2 percentage points from 1990 to 1999 . The share of the top $0.1 \%$ rises from $0.66 \%$ in 1977 to $1.81 \%$ in 1989 , and a further 1.2 percentage points from 1990 to 1999 . The same pattern is exhibited by the shares within shares in Figure 4C: convergence up to1977 and then the UK series rises steadily, while the Netherlands series is little changed.

By dividing the after tax shares by the before tax shares, we get a measure of the arithmetic impact of taxation, referred to as the "implicit tax rate". During this period there have been significant changes in the personal income tax. In the UK the 1979 and 1988 Budgets were major exercises in tax cutting. The extent to which this favoured the very top groups is evident in Figure 5. In those years there was a sharp upward movement in the ratio of the after tax to before tax shares. In the Netherlands the revision of 1990, named after Oort, considerably reduced tax progression, but in exchange for the elimination of a series of deductions meant to broaden the tax-base. It certainly lowered the implicit tax rate, particularly for the top $0.1 \%$, but it gradually eroded over the $1990 \mathrm{~s}$ as in Britain. Also between the 1970s and 1990 the net-gross ratio showed an increase for the $1 \%$ and $0.1 \%$ top shares. Consequently, over the period as a whole the implicit tax rate has fallen in both countries: the graphs have shifted upwards in both countries, indicating reduced progression. In the 1950s the implicit tax rate on the top $0.1 \%$ was around $60 \%$, compared with around $15 \%$ on the top $10 \%$; by the 1990 s the implicit tax rate for the top $0.1 \%$ was around $25-30 \%$, whereas that on the top $10 \%$ was $10-12 \%$. The rates have remained remarkably close together between the two countries. It seems to imply that the remarkable divergence of the top shares after the mid-1970s does not rest on a difference in (effective) tax treatment but on the different evolution of gross income shares at the top. 
Table 2NL NL Shares in Total Before Tax Income 1913-1999

\begin{tabular}{|c|c|c|c|c|c|c|}
\hline \multicolumn{2}{|c|}{ Top 10\% } & \multicolumn{2}{|c|}{ Top 1\% } & Top $0.5 \%$ & \multicolumn{2}{|r|}{ Top $0.05 \%$} \\
\hline 1914 & 45.87 & 36.51 & 20.96 & 16.34 & 8.63 & 6.34 \\
\hline 1915 & 51.21 & 42.07 & 25.58 & 20.31 & 11.44 & 8.58 \\
\hline 1916 & 53.31 & 44.18 & 27.88 & 22.53 & 13.02 & 9.84 \\
\hline 1917 & 52.47 & 42.78 & 26.51 & 21.34 & 12.39 & 9.53 \\
\hline 1918 & 48.50 & 38.20 & 21.95 & 17.18 & 9.65 & 7.40 \\
\hline 1919 & 49.48 & 39.34 & 23.74 & 19.07 & 10.79 & 8.17 \\
\hline 1920 & 46.23 & 35.92 & 20.59 & 16.30 & 8.92 & 6.65 \\
\hline 1921 & 44.03 & 33.35 & 18.29 & 14.23 & 7.60 & 5.65 \\
\hline 1922 & 43.27 & 32.07 & 16.84 & 12.79 & 6.54 & 4.88 \\
\hline 1923 & 43.09 & 31.85 & 16.48 & 12.40 & 6.27 & 4.63 \\
\hline 1924 & 43.84 & 32.77 & 17.36 & 13.22 & 6.84 & 5.15 \\
\hline 1925 & 43.83 & 32.97 & 17.78 & 13.64 & 7.16 & 5.43 \\
\hline 1926 & 43.80 & 32.11 & 18.00 & 13.82 & 7.22 & 5.47 \\
\hline 1927 & 44.33 & 33.72 & 18.37 & 14.13 & 7.39 & 5.47 \\
\hline 1928 & 44.58 & 34.01 & 18.63 & 14.38 & 7.57 & 5.64 \\
\hline 1929 & 43.85 & 33.34 & 18.09 & 13.86 & 7.10 & 5.21 \\
\hline 1930 & 43.02 & 32.41 & 17.15 & 12.97 & 6.47 & 4.69 \\
\hline 1931 & 42.18 & 31.11 & 15.59 & 11.51 & 5.47 & 3.90 \\
\hline 1932 & 41.33 & 30.04 & 14.43 & 10.46 & 4.79 & 3.37 \\
\hline 1933 & 41.19 & 29.91 & 14.20 & 10.24 & 4.63 & 3.24 \\
\hline 1934 & 40.82 & 29.62 & 14.02 & 10.09 & 4.53 & 3.17 \\
\hline 1935 & 40.69 & 29.54 & 14.00 & 10.10 & 4.55 & 3.18 \\
\hline 1936 & 41.10 & 30.18 & 14.83 & 10.89 & 5.15 & 3.70 \\
\hline 1937 & 41.92 & 31.23 & 16.05 & 12.06 & 6.13 & 4.57 \\
\hline 1938 & 41.60 & 30.93 & 15.68 & 11.63 & 5.60 & 4.02 \\
\hline 1939 & 42.03 & 31.29 & 15.80 & 11.64 & 5.54 & 3.91 \\
\hline 1940 & & & & & & \\
\hline 1941 & 45.07 & 34.25 & 17.64 & 13.06 & 6.36 & 4.55 \\
\hline 1942 & & & & & & \\
\hline 1943 & & & & & & \\
\hline 1944 & & & & & & \\
\hline 1945 & & & & & & \\
\hline 1946 & 40.83 & 29.07 & 12.83 & 8.98 & 3.79 & 2.56 \\
\hline 1947 & & & & & & \\
\hline 1948 & & & & & & \\
\hline 1949 & & & & & & \\
\hline 1950 & 36.74 & 26.16 & 12.05 & 8.59 & 3.80 & 2.65 \\
\hline 1951 & & & & & & \\
\hline 1952 & 36.70 & 26.20 & 12.45 & 9.01 & 4.18 & 2.92 \\
\hline 1953 & 36.47 & 25.84 & 11.79 & 8.30 & 3.63 & 2.53 \\
\hline 1954 & 35.94 & 25.47 & 11.65 & 8.26 & 3.61 & 2.50 \\
\hline 1955 & 35.48 & 25.04 & 11.21 & 7.87 & 3.31 & 2.28 \\
\hline 1956 & & & & & & \\
\hline 1957 & 34.29 & 24.02 & 10.54 & 7.32 & 3.04 & \\
\hline 1958 & 35.21 & 24.91 & 11.48 & 8.19 & 3.72 & \\
\hline 1959 & 34.52 & 24.19 & 10.59 & 7.36 & 3.12 & \\
\hline 1960 & 34.10 & 23.80 & 10.30 & 7.11 & 2.90 & \\
\hline
\end{tabular}




\begin{tabular}{ccccccc}
1961 & & & & & & \\
1962 & 34.49 & 24.27 & 10.77 & 7.54 & & \\
1963 & 34.54 & 24.29 & 10.77 & 7.41 & & \\
$1964-34.26$ & 23.83 & 10.38 & 7.23 & & \\
\hline 1964 new & 33.70 & 23.55 & 10.32 & 7.20 & & \\
1965 & 35.71 & 25.41 & 11.91 & 8.70 & & \\
1966 & 33.78 & 23.34 & 9.82 & 6.71 & & \\
1967 & 33.53 & 23.11 & 9.72 & 6.66 & & \\
1968 & 33.04 & 22.92 & 9.84 & 6.83 & & \\
1969 & 31.60 & 21.77 & 9.33 & 6.43 & & \\
1970 & 31.85 & 21.77 & 9.03 & 6.08 & 2.31 & 1.51 \\
1971 & & & & & & \\
1972 & 31.85 & 21.88 & 9.60 & 6.86 & 3.26 & 2.43 \\
1973 & 29.34 & 19.28 & 7.26 & 4.75 & 1.70 & 1.10 \\
1974 & & & & & & \\
1975 & 27.91 & 17.90 & 6.43 & 4.14 & 1.48 & 0.96 \\
1976 & & & & & & \\
1977 & 26.85 & 16.76 & 5.82 & 3.69 & 1.22 & 0.74 \\
1978 & & & & & & \\
1979 & & & & & & \\
1980 & & & & & & \\
1981 & 27.41 & 16.93 & 5.64 & 3.53 & 1.24 & 0.79 \\
1982 & & & & & & \\
1983 & & & & & & \\
1984 & & & & & & \\
1985 & 28.30 & 17.51 & 5.75 & 3.54 & 1.18 & 0.76 \\
1986 & & & & & & \\
1987 & & & & & & \\
1988 & & & & & & \\
1989 & 28.03 & 17.33 & 5.61 & 3.46 & 1.17 & 0.77 \\
1990 & 27.80 & 17.08 & 5.48 & 3.36 & 1.08 & 0.67 \\
1991 & 27.79 & 17.06 & 5.48 & 3.38 & 1.13 & 0.73 \\
1992 & 27.70 & 16.95 & 5.45 & 3.36 & 1.12 & 0.74 \\
1993 & 27.72 & 16.83 & 5.20 & 3.12 & 0.97 & 0.60 \\
1994 & 28.09 & 17.06 & 5.29 & 3.19 & 0.99 & 0.62 \\
1995 & 28.24 & 17.19 & 5.34 & 3.21 & 0.99 & 0.60 \\
1996 & 28.05 & 17.10 & 5.36 & 3.26 & 1.05 & 0.67 \\
1997 & 28.06 & 17.14 & 5.43 & 3.33 & 1.10 & 0.73 \\
1998 & 27.88 & 16.96 & 5.27 & 3.19 & 1.00 & 0.61 \\
1999 & 27.98 & 17.06 & 5.36 & 3.27 & 1.08 & 0.69
\end{tabular}


Table 2UK UK Shares in Total Before Tax Income 1908-1999

Top 10\% Top 5\% Top 1\% Top 0.5\% Top 0.1\% Top $0.05 \%$

\begin{tabular}{|c|c|c|c|c|c|c|}
\hline 1908 & & & & & & 8.22 \\
\hline 1909 & & & & & & 8.31 \\
\hline 1910 & & & & & & 8.37 \\
\hline 1911 & & & & & & 8.38 \\
\hline 1912 & & & & & & 8.38 \\
\hline 1913 & & & & & 11.24 & 8.53 \\
\hline 1914 & & & & & 10.71 & 8.11 \\
\hline 1915 & & & & & 10.77 & 8.17 \\
\hline 1916 & & & & & 10.47 & 7.97 \\
\hline 1917 & & & & & 9.26 & 7.06 \\
\hline 1918 & 37.03 & 30.35 & 19.24 & 15.46 & 8.68 & 6.58 \\
\hline 1919 & 38.73 & 31.48 & 19.59 & 15.69 & 8.98 & 6.79 \\
\hline 1920 & & & & & 8.03 & 6.06 \\
\hline 1921 & & & & & 8.08 & 6.04 \\
\hline 1922 & & & & & 9.07 & 6.78 \\
\hline 1923 & & & & & 9.29 & 6.95 \\
\hline 1924 & & & & & 9.05 & 6.74 \\
\hline 1925 & & & & & 8.79 & 6.53 \\
\hline 1926 & & & & & 8.67 & 6.42 \\
\hline 1927 & & & & & 8.49 & 6.28 \\
\hline 1928 & & & & & 8.54 & 6.34 \\
\hline 1929 & & & & & 8.33 & 6.15 \\
\hline 1930 & & & & & 7.81 & 5.74 \\
\hline 1931 & & & & & 7.17 & 5.24 \\
\hline 1932 & & & & & 6.87 & 5.00 \\
\hline 1933 & & & & & 6.75 & 4.91 \\
\hline 1934 & & & & & 6.78 & 4.92 \\
\hline 1935 & & & & & 6.96 & 5.08 \\
\hline 1936 & & & & & 7.03 & 5.12 \\
\hline 1937 & 38.37 & 29.75 & 16.98 & 13.07 & 6.59 & 4.78 \\
\hline 1938 & & & & & 6.57 & 4.79 \\
\hline 1939 & & & & & 6.36 & 4.62 \\
\hline 1940 & & & & & 5.67 & 4.09 \\
\hline 1941 & & & & & 5.00 & 3.57 \\
\hline 1942 & & & & & 4.44 & 3.15 \\
\hline 1943 & & & & 9.04 & 4.23 & 2.98 \\
\hline 1944 & & & & 8.97 & 4.13 & 2.90 \\
\hline 1945 & & & & 9.38 & 4.23 & 2.95 \\
\hline 1946 & & & & 10.00 & 4.48 & 3.10 \\
\hline 1947 & & & & 9.38 & 4.10 & 2.81 \\
\hline 1948 & & & & 8.88 & 3.86 & 2.63 \\
\hline 1949 & 32.25 & 23.39 & 11.47 & 8.12 & 3.45 & 2.34 \\
\hline 1950 & & & & 8.51 & 3.59 & 2.42 \\
\hline 1951 & & & 10.89 & 7.69 & 3.21 & 2.15 \\
\hline 1952 & & & 10.20 & 7.15 & 2.95 & 1.97 \\
\hline 1953 & & & 9.72 & 6.78 & 2.77 & 1.84 \\
\hline 1954 & 30.63 & 21.22 & 9.67 & 6.71 & 2.72 & 1.80 \\
\hline 1955 & & & 9.30 & 6.48 & 2.65 & 1.77 \\
\hline
\end{tabular}




\begin{tabular}{|c|c|c|c|c|c|c|}
\hline 1956 & & & 8.75 & 6.03 & 2.42 & 1.60 \\
\hline 1957 & & & 8.70 & 5.96 & 2.37 & 1.57 \\
\hline 1958 & & & 8.76 & 5.98 & 2.38 & 1.57 \\
\hline 1959 & 29.96 & 20.26 & 8.60 & 5.85 & 2.30 & 1.52 \\
\hline \multicolumn{7}{|l|}{1960} \\
\hline \multicolumn{7}{|l|}{1961} \\
\hline 1962 & 29.37 & 19.72 & 8.43 & 5.76 & 2.29 & 1.52 \\
\hline 1963 & 29.94 & 20.10 & 8.49 & 5.76 & 2.23 & 1.47 \\
\hline 1964 & 29.91 & 20.07 & 8.48 & 5.77 & 2.26 & 1.49 \\
\hline 1965 & 29.88 & 20.10 & 8.55 & 5.79 & 2.28 & 1.52 \\
\hline 1966 & 28.94 & 19.22 & 7.92 & 5.32 & 2.04 & 1.37 \\
\hline 1967 & 28.78 & 18.99 & 7.69 & 5.11 & 1.91 & 1.25 \\
\hline 1968 & 28.55 & 18.76 & 7.54 & 5.00 & 1.87 & 1.21 \\
\hline 1969 & 28.72 & 18.86 & 7.46 & 4.96 & 1.85 & 1.22 \\
\hline 1970 & 28.82 & 18.65 & 7.05 & 4.59 & 1.64 & 1.05 \\
\hline 1971 & 29.29 & 18.81 & 7.02 & 4.56 & 1.67 & 1.09 \\
\hline 1972 & 28.90 & 18.48 & 6.94 & 4.52 & 1.61 & 1.04 \\
\hline 1973 & 28.31 & 18.18 & 6.99 & 4.59 & 1.68 & 1.08 \\
\hline 1974 & 28.10 & 17.77 & 6.54 & 4.29 & 1.58 & 1.02 \\
\hline 1975 & 27.82 & 17.40 & 6.10 & 3.92 & 1.40 & 0.91 \\
\hline 1976 & 27.89 & 17.33 & 5.89 & 3.75 & 1.30 & 0.86 \\
\hline 1977 & 27.96 & 17.33 & 5.93 & 3.75 & 1.27 & 0.82 \\
\hline 1978 & 27.78 & 17.11 & 5.72 & 3.60 & 1.24 & 0.79 \\
\hline 1979 & 28.37 & 17.57 & 5.93 & 3.76 & 1.30 & 0.83 \\
\hline \multicolumn{7}{|l|}{1980} \\
\hline 1981 & 31.03 & 19.45 & 6.67 & 4.27 & 1.53 & 0.99 \\
\hline 1982 & 31.23 & 19.65 & 6.85 & 4.40 & 1.61 & 1.07 \\
\hline 1983 & 31.76 & 19.98 & 6.83 & 4.36 & 1.58 & 1.04 \\
\hline 1984 & 32.52 & 20.67 & 7.16 & 4.54 & 1.67 & 1.10 \\
\hline 1985 & 32.65 & 20.75 & 7.40 & 4.83 & 1.82 & \\
\hline 1986 & 32.94 & 21.04 & 7.55 & 4.92 & 1.86 & \\
\hline 1987 & 33.27 & 21.38 & 7.78 & 5.04 & & \\
\hline 1988 & 34.21 & 22.37 & 8.63 & 5.80 & & \\
\hline 1989 & 34.15 & 22.51 & 8.67 & 5.90 & & \\
\hline 1990 & 36.90 & 24.43 & 9.80 & 6.72 & & \\
\hline 1991 & 37.65 & 25.13 & 10.32 & 7.18 & & \\
\hline 1992 & 37.64 & 24.89 & 9.86 & 6.74 & & \\
\hline 1993 & 38.34 & 25.51 & 10.36 & 7.20 & 3.09 & \\
\hline 1994 & 38.33 & 25.62 & 10.60 & 7.36 & 3.10 & \\
\hline 1995 & 38.54 & 25.86 & 10.77 & 7.56 & 3.29 & \\
\hline 1996 & 39.31 & 26.87 & 11.88 & 8.63 & 4.12 & \\
\hline 1997 & 38.93 & 26.78 & 12.06 & 8.75 & & \\
\hline 1998 & 39.57 & 27.45 & 12.54 & 9.10 & & \\
\hline 1999 & 40.52 & 28.16 & 12.99 & & & \\
\hline
\end{tabular}

Note: italics denote linear bounds differ by more than specified amount. 
Table 3NL NL Shares in Disposable Income 1959-1999

Top 10\% Top 5\% Top 1\% Top 0.5\% Top 0.1\% Top 0.05\%

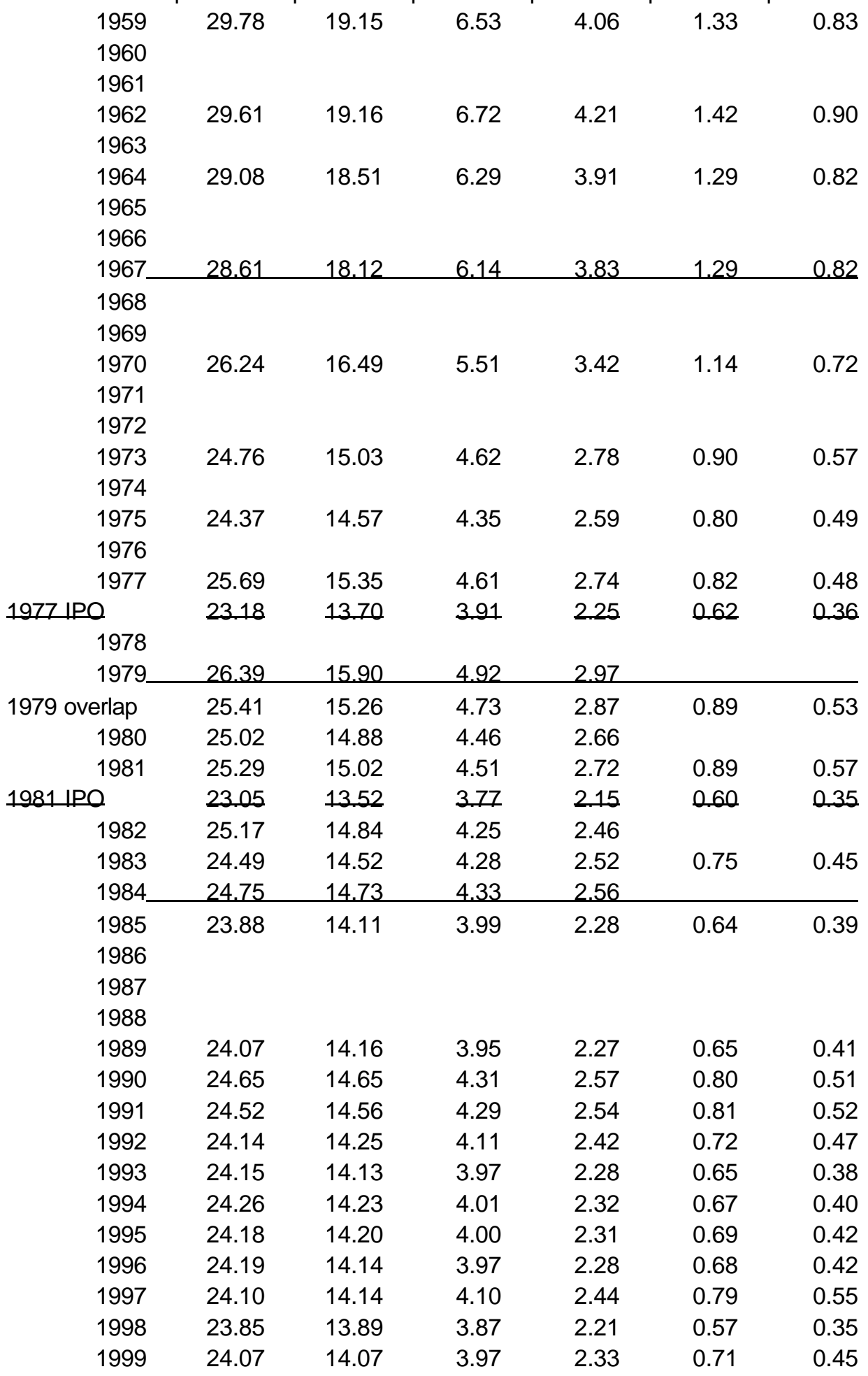

Note: italics denotes linear bounds differ by more than specified amount. 
Table 3UK UK Shares in Total After Tax Income 1937-1999

Top 10\% Top 5\% Top 1\% Top 0.5\% Top 0.1\% Top 0.05\%

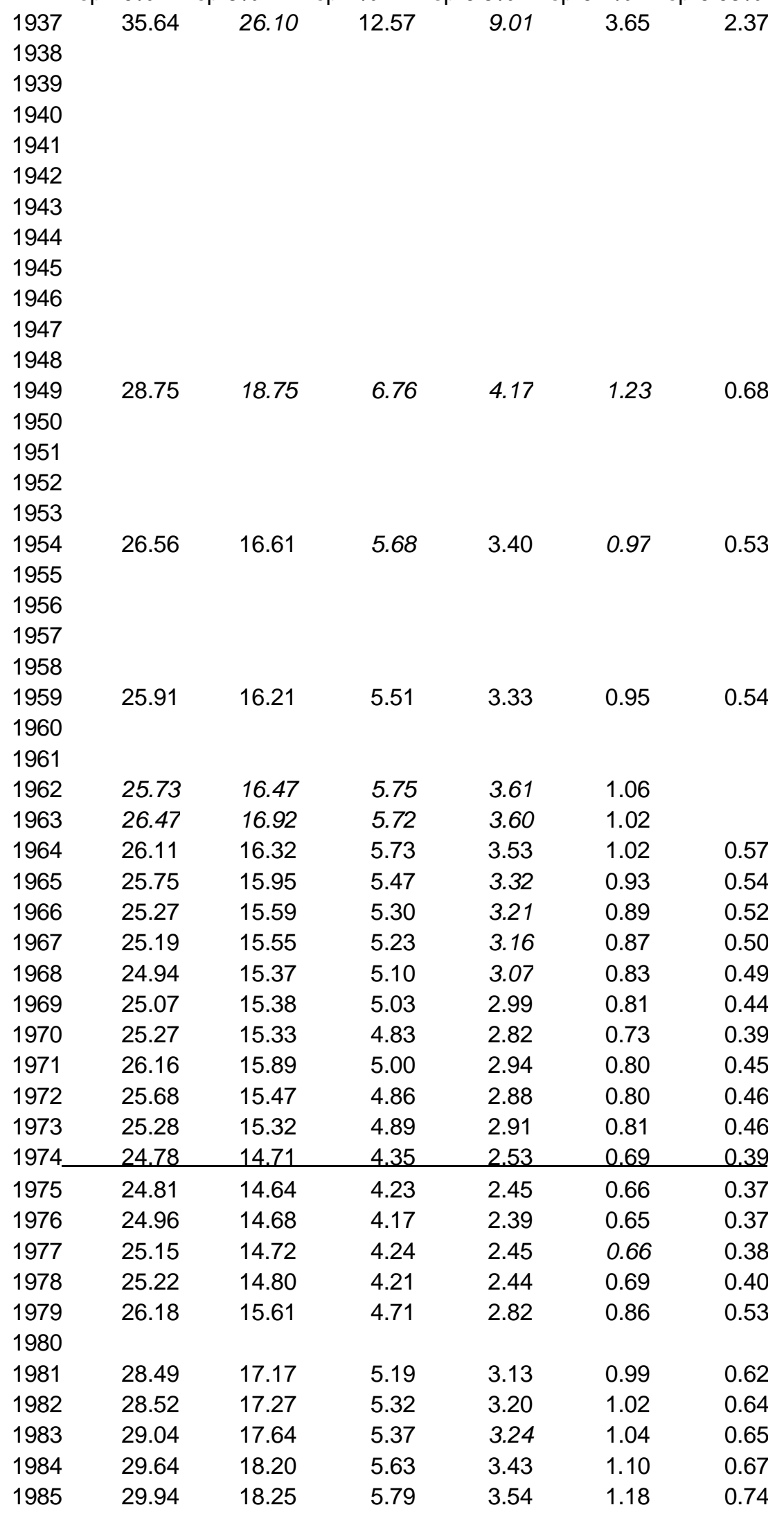




$\begin{array}{lllrlll}1986 & 30.03 & 18.40 & 5.80 & 3.56 & 1.21 & 0.77 \\ 1987 & 30.29 & 18.64 & 5.90 & 3.63 & 1.20 & 0.76 \\ 1988 & 31.54 & 19.84 & 7.05 & 4.65 & 1.83 & 1.13 \\ 1989 & 31.29 & 19.92 & 7.14 & 4.66 & 1.81 & \\ 1990 & 33.92 & 21.73 & 8.02 & 5.41 & 2.21 & \\ 1991 & 34.52 & 22.20 & 8.35 & 5.67 & 2.35 & \\ 1992 & 34.47 & 21.96 & 8.01 & 5.37 & 2.01 & \\ 1993 & 34.94 & 22.48 & 8.45 & 5.75 & 2.37 & 1.61 \\ 1994 & 34.78 & 22.60 & 8.56 & 5.78 & 2.35 & 1.60 \\ 1995 & 34.94 & 22.55 & 8.71 & 5.91 & 2.49 & 1.72 \\ 1996 & 35.48 & 23.33 & 9.55 & 6.71 & 3.11 & 2.25 \\ 1997 & 35.24 & 23.39 & 9.76 & 6.91 & 3.28 & 2.41 \\ 1998 & 35.55 & 23.32 & 9.99 & 7.11 & 3.37 & \\ 1999 & 36.28 & 24.31 & 10.17 & 7.24 & & \end{array}$

Note: italics denotes linear bounds differ by more than specified amount. 


\section{Conclusions}

The aim of this paper has been to set side by side the evidence from income tax data about the distribution of top incomes in the Netherlands and the UK over the twentieth century. For reasons detailed in the text, the estimates are not fully comparable across the two countries, and there are breaks in comparability over time. Nevertheless, we feel that the main conclusions are sufficiently robust to be taken as a starting point for a search for explanations.

Simply stated, the distributions of top incomes evolve in an astonishingly parallel manner from 1914 to 1977 and then diverge to a degree that is equally surprising. For the first threequarters of the century, there was a major fall in the top shares in before tax income. There was a similar fall in the shares of top incomes after tax for the shorter period for which we have data, despite the apparent reductions in tax progression. This changed in the last quarter century. Top shares, and the inequality within the top group, rose sharply in the UK after 1977, whereas there is little apparent change in the Netherlands. In terms of other countries, for the last part of the century the UK resembled the US and the Netherlands resembled France - witness the results found by Piketty and Saez. 


\section{Appendix A Sources of Tabulated Income Tax Data for the Netherlands}

The tabulated income data come from a variety of sources. The first is the series of annual statistical yearbooks: JC denotes JaarCijfers voor het Koninkrijk der Nederlanden and SY denotes Statistical Yearbook of the Netherlands (in English). The second main source is the series of publications on the public finances: SR denotes Statistiek der Rijksfinancien. This was then replaced for this purpose by the regular studies of income distribution referred to in the text as IenV: Inkomens- en Vermogensverdeling (sometimes Inkomens $X$ en Vermogensverdeling $X+$ ).

Table A1 Sources for NL Data on Total Income

\begin{tabular}{|c|c|c|c|c|c|c|c|}
\hline $\begin{array}{l}\text { Tax } \\
\text { Year }\end{array}$ & $\begin{array}{l}\text { Assumed } \\
\text { Income } \\
\text { year (if } \\
\text { different) } \\
\end{array}$ & $\begin{array}{l}\text { Lower } \\
\text { limit } \\
\text { guilders }\end{array}$ & $\begin{array}{l}\text { Number of } \\
\text { taxpayers } \\
\text { Thousands }\end{array}$ & \begin{tabular}{|l} 
Total \\
income \\
Million \\
guilders \\
\end{tabular} & $\begin{array}{l}\% \\
\text { married? }\end{array}$ & Source & Notes \\
\hline 1915/16 & 1914 & 650 & 679.1 & 1334.5 & $X$ & JC 1921, p 147 & $\begin{array}{l}\text { Tax introduced } 1 \\
\text { May } 1915\end{array}$ \\
\hline $1916 / 17$ & 1915 & 650 & 757.5 & 1724.7 & $\mathrm{X}$ & JC $1918, \mathrm{p} 154$ & \\
\hline $1917 / 18$ & 1916 & 650 & 876.0 & 2064.8 & $X$ & JC 1921, p 147 & $\begin{array}{l}\text { Including } \\
\text { payments in } \\
\text { arrears }\end{array}$ \\
\hline $1918 / 19$ & 1917 & 650 & 897.2 & 2140.2 & $\mathrm{X}$ & JC 1920, p 145 & $\begin{array}{l}\text { Suspension of } \\
\text { interest payments } \\
\text { on Russian } \\
\text { national debt; } \\
\text { including } \\
\text { payments in } \\
\text { arrears } \\
\end{array}$ \\
\hline $1919 / 20$ & 1918 & 800 & 966.0 & 2431.9 & $\mathrm{X}$ & JC 1921, p 147 & $\begin{array}{l}\text { Increase in tax } \\
\text { threshold; } \\
\text { Including } \\
\text { payments in } \\
\text { arrears } \\
\end{array}$ \\
\hline $1920 / 21$ & 1919 & 800 & 1368.3 & 3638.9 & $\mathrm{X}$ & JC 1921, p 147 & $\begin{array}{l}\text { Large increase in } \\
\text { prices; } 1 \text { May } \\
1919 \text { considerable } \\
\text { increase in tax } \\
\text { introduced }\end{array}$ \\
\hline $1921 / 22$ & 1920 & 800 & 1638.4 & 4291.7 & $X$ & JC 1923, p 139 & \\
\hline $1922 / 23$ & 1921 & 800 & 1690.2 & 4138.3 & $\mathrm{X}$ & JC 1923, p 139 & $\begin{array}{l}\text { Influence of fall in } \\
\text { prices and } \\
\text { economic crisis }\end{array}$ \\
\hline $1923 / 24$ & 1922 & 800 & 1632.0 & 3848.3 & $\mathrm{X}$ & JC 1925, p 141 & $\begin{array}{l}\text { Influence of fall in } \\
\text { prices and } \\
\text { economic crisis }\end{array}$ \\
\hline $1924 / 25$ & 1923 & 800 & 1624.6 & 3761.3 & $\mathrm{X}$ & JC 1925, p 141 & $\begin{array}{l}\text { Influence of fall in } \\
\text { prices and } \\
\text { economic crisis }\end{array}$ \\
\hline $1925 / 26$ & 1924 & 800 & 1657.9 & 3863.9 & $\mathrm{X}$ & JC $1927, \mathrm{p} 145$ & \\
\hline $1926 / 27$ & 1925 & 800 & 1694.0 & 3902.8 & $\mathrm{X}$ & JC 1929, p 150 & \\
\hline
\end{tabular}




\begin{tabular}{|c|c|c|c|c|c|c|c|}
\hline $1927 / 28$ & 1926 & 800 & 1719.4 & 3932.3 & $\mathrm{X}$ & JC $1929, p 150$ & \\
\hline $1928 / 29$ & 1927 & 800 & 1746.1 & 4028.6 & $\mathrm{X}$ & SR 1933, p 18 & $\begin{array}{l}1 \text { May } 1928 \text { tax } \\
\text { rate reduced }\end{array}$ \\
\hline $1929 / 30$ & 1928 & 800 & 1830.9 & 4284.9 & $\mathrm{X}$ & SR 1933, p 18 & $\begin{array}{l}1929 \text { economic } \\
\text { crisis had little } \\
\text { effect on the } \\
\text { figures for1929/30 } \\
\text { (SR 1929-1931, p } \\
\text { 25, note 16) } \\
\end{array}$ \\
\hline $1930 / 31$ & 1929 & 800 & 1892.6 & 4367.2 & $\mathrm{X}$ & SR 1933, p 18 & \\
\hline $1931 / 32$ & 1930 & 800 & 1867.2 & 4206 & Yes & SR 1933, p 18 & $\begin{array}{l}\begin{array}{l}\text { First year when } \\
\text { married/single split } \\
\text { given }\end{array} \\
\end{array}$ \\
\hline $1932 / 33$ & 1931 & 800 & 1668.2 & 3657.2 & Yes & SR 1936, p 22 & \\
\hline $1933 / 34$ & 1932 & 800 & 1484.6 & 3156.8 & Yes & SR 1936, p 22 & \\
\hline $1934 / 35$ & 1933 & 800 & 1445.0 & 3042.0 & Yes & SR 1936, p 22 & \\
\hline $1935 / 36$ & 1934 & 800 & 1355.1 & 2828.0 & Yes & SR 1938, p 22 & \\
\hline $1936 / 37$ & 1935 & 800 & 1284.6 & 2666.0 & Yes & SR 1938, p 22 & \\
\hline $1937 / 38$ & 1936 & 800 & 1304.2 & 2738.1 & Yes & SR 1939, p 22 & \\
\hline $1938 / 39$ & 1937 & 800 & 1364.4 & 2933.8 & Yes & SR 1940, Tabel XVL & \begin{tabular}{|l|} 
Reference to \\
effect of \\
devaluation of 28 \\
September 1936 \\
\end{tabular} \\
\hline $1939 / 40$ & 1938 & 800 & 1409.2 & 3009.9 & Yes & \begin{tabular}{|l} 
SR 1941 \\
\end{tabular} & \\
\hline $1940 / 41$ & 1939 & 800 & 1536.4 & 3295.9 & $\mathrm{X}$ & JC 1943-1946, p 342 & Refers to timing \\
\hline 1941 & & 1000 & 2838.4 & 4645.3 & $\begin{array}{l}\text { Yes } \\
\text { (Tariff } \\
\text { Groups } \\
\text { II and } \\
\text { III) } \\
\end{array}$ & JC 1947-1950, p 268 & $\begin{array}{l}\text { No figures } \\
\text { available for 1942- } \\
1945\end{array}$ \\
\hline 1946 & & 1000 & 3605.4 & 7696.2 & $\begin{array}{l}\text { Yes } \\
\text { (Tariff } \\
\text { Groups } \\
\text { II and } \\
\text { III) } \\
\end{array}$ & JC 1951-1952, p 270 & \\
\hline 1950 & & - & 3994.3 & 12100.0 & \begin{tabular}{|l|} 
JC 1953- \\
$1954, p$ \\
272 \\
(slightly \\
different \\
figures \\
for total) \\
\end{tabular} & $\begin{array}{l}\text { JC 1963-1964, p 308; see } \\
\text { also JC 1953-1954, p } 272 \\
\text { where slightly different } \\
\text { figures for total (also } \\
\text { given in IenV 1952, p } 10\end{array}$ & $\begin{array}{l}\text { Married/single } \\
\text { given for earlier } \\
\text { figures }\end{array}$ \\
\hline 1952 & & - & 4012.0 & 13778 & & IenV 1952, p 10 & \\
\hline 1953 & & - & 4079 & 14420 & & IenV $1955, \mathrm{p} 9$ & \\
\hline 1954 & & - & 4208 & 16470 & & IenV $1955, \mathrm{p} 9$ & \\
\hline 1955 & & - & 4280.3 & 18350.2 & & IenV $1955, \mathrm{p} 9$ & \\
\hline 1957 & & - & 4567 & 22405 & Yes & IenV 1957, Tabel 3 & \\
\hline 1958 & & - & 4606 & 23712 & Yes & IenV 1958, Tabel 3 & \\
\hline 1959 & & - & 4689.0 & 24796 & Yes & IenV 1959, Tabel 3 & \\
\hline 1960 & & - & 4802.7 & 27684.5 & Yes & IenV 1960, Tabel 1 & \\
\hline
\end{tabular}




\begin{tabular}{|c|c|c|c|c|c|c|}
\hline 1962 & & 5099.6 & 32887.8 & Yes & IenV 1962, Tabel 3 & $\begin{array}{l}\text { Change in method } \\
\text { of allocating to } \\
\text { income classes }\end{array}$ \\
\hline 1963 & - & 5285 & 36265 & & SY 1969-1970, p 278 & \\
\hline 1964 & - & 5316.6 & 42780.2 & Yes & IenV 1964, Tabel 3 & \\
\hline $\begin{array}{l}1964 \\
\text { new } \\
\text { basis }\end{array}$ & - & 5316.6 & 41056 & & IenV 1966, p 18 & \\
\hline 1965 & - & 5657.6 & 47564 & & IenV 1966, p 19 & \\
\hline 1966 & - & 5776.3 & 51659.7 & Yes & IenV $1966, \mathrm{p} 28$ & \\
\hline 1967 & - & 5735 & 55901 & Yes & IenV 1967, p 20 & \\
\hline 1968 & 15000 & 904 & 25308 & & SY 1974, p 286 & \begin{tabular}{|l|} 
Truncated below \\
at 15000 \\
\end{tabular} \\
\hline 1969 & 15000 & 1148 & 31152 & & SY 1974, p 286 & \begin{tabular}{|l|} 
Truncated below \\
at 15000 \\
\end{tabular} \\
\hline 1970 & - & 5631 & \begin{tabular}{|l|}
76238.8 \\
\end{tabular} & Yes & IenV 1970, Tabel 3 & \\
\hline 1972 & - & 6379.7 & 96988.2 & & SY 1976, p 300 & \\
\hline 1973 & - & 6490.8 & 109524.1 & Yes & SY, 1977, p 300 & \\
\hline 1975 & - & 5679.9 & 138891 & & SY 1979, p 317 & \\
\hline 1979 & - & 6638.9 & & $\begin{array}{l}\text { Only for } \\
\text { full year } \\
\text { incomes } \\
\end{array}$ & & $\begin{array}{l}\text { Only numbers, not } \\
\text { amounts }\end{array}$ \\
\hline 1977 & & $6,352.0$ & 206,684 & Yes & \multirow{14}{*}{$\begin{array}{l}\text { Inkomenspanelonderzoek } \\
\text { IPO }\end{array}$} & \multirow{14}{*}{$\begin{array}{l}\text { see Nierop and } \\
\text { Salverda (2003) } \\
\text { for details }\end{array}$} \\
\hline 1981 & & $6,842.3$ & 262,741 & Yes & & \\
\hline 1985 & & $7,461.4$ & 291,083 & Yes & & \\
\hline 1989 & & $7,961.7$ & 351,414 & Yes & & \\
\hline 1990 & & $8,105.4$ & 407,289 & Yes & & \\
\hline 1991 & & $8,221.7$ & 431,711 & Yes & & \\
\hline 1992 & & $8,308.6$ & 456,142 & Yes & & \\
\hline 1993 & & $8,401.4$ & 460,075 & Yes & & \\
\hline 1994 & & $8,484.3$ & 464,977 & Yes & & \\
\hline 1995 & & $8,538.2$ & 480,660 & Yes & & \\
\hline 1996 & & $8,613.6$ & 493,609 & Yes & & \\
\hline 1997 & & $8,698.1$ & 510,376 & Yes & & \\
\hline 1998 & & $8,757.9$ & 535,214 & Yes & & \\
\hline 1999 & & $8,851.8$ & 565,901 & Yes & & \\
\hline
\end{tabular}




\section{Table A2 Sources for NL Data on Disposable Income}

Data on disposable (besteedbaar) income is published in IenV (see Table A1) and the monthly SEM: Sociaal-Economische Maandstatistiek.

\begin{tabular}{|c|c|c|c|c|}
\hline Year & $\begin{array}{l}\text { Total } \\
\text { tax } \\
\text { units }\end{array}$ & $\begin{array}{l}\text { Total } \\
\text { disposable } \\
\text { income }\end{array}$ & Source & Notes \\
\hline 1959 & 4,689 & 20,825 & IenV, 1959, Tabel 12 & \\
\hline 1959 & $4,257.6$ & $20,166.3$ & SEM, 1987, 6, Tabel 1.1 & Full year incomes \\
\hline 1962 & 5,100 & 27,954 & IenV, 1962, Tabel 9 & \\
\hline 1962 & $4,567.5$ & $26,977.7$ & SEM, 1987, 6, Tabel 1.2 & Full year incomes \\
\hline 1964 & 5,317 & 35,961 & IenV, 1964, Tabel 13 & \\
\hline 1964 & $4,678.4$ & $34,559.3$ & SEM, 1987, 6, Tabel 1.3 & Full year incomes \\
\hline 1966 & 5,776 & 42,973 & IenV, 1966, p 28 & \\
\hline 1967 & $4,972.1$ & $45,362.9$ & $\begin{array}{l}\text { SEM, 1987, 6, Tabel 1.4, IenV } \\
\text { 1967, p } 20\end{array}$ & Full year incomes \\
\hline 1970 & 5,631 & 66,010 & IenV, 1966, Tabel 13 & \\
\hline 1970 & $5,240.6$ & $62,271.0$ & SEM, 1987, 6, Tabel 1.5 & $\begin{array}{l}\text { Full year incomes; excludes } \\
\text { imputed rent on owner- } \\
\text { occupied housing }\end{array}$ \\
\hline 1973 & 5,889 & 93,812 & IenV, 1973, Tabel 12 & \\
\hline 1973 & $5,573.4$ & $89,144.5$ & SEM, 1987, 6, Tabel 1.6 & $\begin{array}{l}\text { Full year incomes; excludes } \\
\text { imputed rent on owner- } \\
\text { occupied housing }\end{array}$ \\
\hline 1975 & $5,699.2$ & 115,636 & SEM, 1987, 6, Tabel 1.7 & $\begin{array}{l}\text { Full year incomes; excludes } \\
\text { imputed rent on owner }\end{array}$ \\
\hline 1977 & $5,771.4$ & $138,694.4$ & SEM, 1987, 6, Tabel 1.8 & $\begin{array}{l}\text { Full year incomes; excludes } \\
\text { imputed rent on owner }\end{array}$ \\
\hline 1979 & $5,877.2$ & $162,192.8$ & SEM, 1987, 6, Tabel 1.9 & $\begin{array}{l}\text { Full year incomes; excludes } \\
\text { imputed rent on owner }\end{array}$ \\
\hline 1979 & $5,877.2$ & $155,587.2$ & SEM, 1987, 6, Tabel 1.10 & Full year incomes \\
\hline 1980 & $5,977.5$ & 165,611 & SEM, 1987, 6, Tabel 1.11 & Full year incomes \\
\hline 1981 & $6,014.8$ & $171,033.3$ & SEM, 1987, 6, Tabel 1.12 & Full year incomes \\
\hline 1982 & $6,025.6$ & $175,816.8$ & SEM, 1987, 6, Tabel 1.13 & Full year incomes \\
\hline 1983 & $6,399.3$ & $184,717.2$ & SEM, 1987, 6, Tabel 1.14 & Full year incomes \\
\hline 1984 & $6,553.5$ & $187,949.9$ & SEM, 1987, 6, Tabel 1.15 & Full year incomes \\
\hline 1977 & $6,352.0$ & 134,923 & \multirow[t]{12}{*}{ Inkomenspanelonderzoek IPO } & \multirow{12}{*}{$\begin{array}{l}\text { includes imputed rent for } \\
\text { owner-occupied housing. } \\
\text { See Nierop and Salverda } \\
\text { (2003) for more details }\end{array}$} \\
\hline 1981 & $6,842.3$ & 171,365 & & \\
\hline 1985 & $7,461.4$ & 192,620 & & \\
\hline 1989 & $7,961.7$ & 231,484 & & \\
\hline 1990 & $8,105.4$ & 251,742 & & \\
\hline 1991 & $8,221.7$ & 264,665 & & \\
\hline 1992 & $8,308.6$ & 274,318 & & \\
\hline 1993 & $8,401.4$ & 281,968 & & \\
\hline 1994 & $8,484.3$ & 292,009 & & \\
\hline 1995 & $8,538.2$ & 305,420 & & \\
\hline 1996 & $8,613.6$ & 314,998 & & \\
\hline 1997 & $8,698.1$ & 328,803 & & \\
\hline
\end{tabular}




\begin{tabular}{|l|l|l|l|l|}
\hline 1998 & $8,757.9$ & 343,465 & & \\
\hline 1999 & $8,851.8$ & 358,009 & & \\
\hline
\end{tabular}




\section{Appendix B Sources of Tabulated Income Data for the UK}

The super-tax/surtax are taken from published tabulations, mostly from the Annual Reports of the Commissioners of Her Majesty's Inland Revenue, referred to as AR, or in the more recent years from Inland Revenue Statistics, referred to as IRS.

Table B1 Sources for UK Super-Tax and Surtax Data

\begin{tabular}{|c|c|c|}
\hline Income year & $\begin{array}{l}\text { Super-tax/surtax year } \\
\text { (where different) }\end{array}$ & Source \\
\hline 1908-09 & $1909-10$ & Royal Commission on the Income Tax, 1920a, page 26 \\
\hline 1909-10 & $1910-11$ & Royal Commission on the Income Tax, 1920a, page 26 \\
\hline $1910-11$ & $1911-12$ & AR 1914-15, page 134 \\
\hline $1911-12$ & $1912-13$ & AR 1914-15, page 134 \\
\hline $1912-13$ & $1913-14$ & AR 1915-16, page 49 \\
\hline 1913-14 & $1914-15$ & AR 1917-18, page 19 \\
\hline $1914-15$ & $1915-16$ & AR 1918-19, page 19 \\
\hline 1915-16 & 1916-17 & AR 1919-20, page 85 \\
\hline $1916-17$ & $1917-18$ & AR 1920-21, page 136 \\
\hline $1917-18$ & 1918-19 & AR 1921-22, page 145 \\
\hline 1918-19 & $1919-20$ & AR 1922-23, page 98 \\
\hline $1919-20$ & $1920-21$ & AR 1923-24, page 110 \\
\hline $1920-21$ & $1921-22$ & AR 1924-25, page 109 \\
\hline $1921-22$ & $1922-23$ & AR 1927-28, page 96 \\
\hline $1922-23$ & $1923-24$ & AR 1928-29, page 94 \\
\hline 1923-24 & $1924-25$ & AR 1929-30, page 88 \\
\hline 1924-25 & $1925-26$ & AR 1930-31, page 95 \\
\hline $1925-26$ & $1926-27$ & AR 1931-32, page 82 \\
\hline $1926-27$ & $1927-28$ & AR 1932-33, page 83 \\
\hline $1927-28$ & $1928-29$ & AR 1933-34, page 81 \\
\hline 1928-29 & & AR 1933-34, page 81 \\
\hline 1929-30 & & AR 1934-35, page 80 \\
\hline 1930-31 & & AR 1935-36, page 67 \\
\hline $1931-32$ & & AR 1936-37, page 67 \\
\hline $1932-33$ & & AR $1937-38$, page 65 \\
\hline 1933-34 & & AR 1938-39, page 71 \\
\hline 1934-35 & & AR 1939-40, page 44 \\
\hline 1935-36 & & AR 1940-41, page 35 \\
\hline 1936-37 & & AR 1941-42, page 36 \\
\hline $1937-38$ & & AR 1942-43, page 29 \\
\hline 1938-39 & & AR 1942-43, page 29 \\
\hline $1939-40$ & & AR 1942-43, page 29 \\
\hline 1940-41 & & AR 1943-44, page 27 \\
\hline $1941-42$ & & AR 1946-47, page 83 \\
\hline $1942-43$ & & AR 1947-48, page 44 \\
\hline 1943-44 & & AR 1948-49, page 98 \\
\hline $1944-45$ & & AR 1949-50, page 57 \\
\hline $1945-46$ & & AR 1950-51, page 136 \\
\hline
\end{tabular}




\begin{tabular}{|l|l|l|}
\hline $1946-47$ & & AR 1951-52, page 154 \\
\hline $1947-48$ & AR 1953-54, page 81 \\
\hline $1948-49$ & AR 1954-55, page 78 \\
\hline $1949-50$ & & AR 1955-56, page 105 \\
\hline $1950-51$ & & AR 1956-57, page 144 \\
\hline $1951-52$ & AR 1957-58, page 96 \\
\hline $1952-53$ & & AR 1957-58, page 96 \\
\hline $1953-54$ & & AR 1958-59, page 82 \\
\hline $1954-55$ & & AR 1959-60, page 84 \\
\hline $1955-56$ & & AR 1959-60, page 84 \\
\hline $1956-57$ & & AR 1960-61, page 92 \\
\hline $1957-58$ & & AR 1961-62, page 207 \\
\hline $1958-59$ & & AR 1962-63, page 99 \\
\hline $1959-60$ & & AR 1963-64, page 101 \\
\hline $1960-61$ & & Not used (data incomplete) \\
\hline $1961-62$ & & Not available \\
\hline $1962-63$ & & AR 1964-65, page 100 \\
\hline $1963-64$ & & AR 1965-66, page 86 \\
\hline $1964-65$ & & AR 1966-67, page 111 \\
\hline $1965-66$ & & AR 1967-68, page 86 \\
\hline $1966-67$ & & IRS 1970, page 48 \\
\hline $1967-68$ & & IRS 1971, page 53 \\
\hline $1968-69$ & & IRS 1972, page 53 \\
\hline $1969-70$ & & IRS 1973, page 56 \\
\hline $1970-71$ & & IRS 1974, page 24 \\
\hline $1971-72$ & & IRS 1975, page 22 \\
\hline $1972-73$ & & IRS 1975, page 22 \\
\hline
\end{tabular}




\section{Table B2 Sources of UK SPI Data}

The SPI data are taken from AR or IRS (see Table B1) or the special reports on the SPI, referred to as SPI, or one-off sources such as the report of the Colwyn Committee (1927).

\begin{tabular}{|c|c|c|c|}
\hline $\begin{array}{l}\text { Income } \\
\text { tax } \\
\text { assessmen } \\
\text { t year }\end{array}$ & $\begin{array}{c}\text { Nature of } \\
\text { survey }\end{array}$ & $\begin{array}{l}\text { Lower limit } \\
£ \text { year (\% } \\
\text { mean tax } \\
\text { unit } \\
\text { income) }\end{array}$ & Source (s) \\
\hline $1918-19$ & $\begin{array}{l}\text { special } \\
\text { exercise }\end{array}$ & 130 & AR 1919-20, page 70 \\
\hline $1919-20$ & $\begin{array}{l}\text { special } \\
\text { exercise }\end{array}$ & 130 & Colwyn Committee (1927), Appendix XIV \\
\hline $1937-38$ & $\begin{array}{l}\text { special } \\
\text { exercise }\end{array}$ & 200 & $\begin{array}{l}\text { AR 1939-40, page 30; income after tax from AR 1948-49, } \\
\text { page 83. }\end{array}$ \\
\hline $1949-50$ & quinquennial & 135 & $\begin{array}{l}\text { AR 1950-51, page } 97 \text { before adjustment for wives' earnings } \\
\text { deficiency; income after tax from AR 1950-51, page 117, after } \\
\text { adjustment for wives' earnings deficiency. }\end{array}$ \\
\hline $1954-55$ & quinquennial & $\begin{array}{c}155 \\
(33.2 \%)\end{array}$ & $\begin{array}{l}\text { AR 1955-56, page } 67 \text { before adjustment for wives' earnings } \\
\text { deficiency; income after tax from AR 1955-6, page 94, after } \\
\text { adjustment for wives' earnings deficiency. }\end{array}$ \\
\hline $1959-60$ & quinquennial & $\begin{array}{c}180 \\
(29.0 \%)\end{array}$ & $\begin{array}{l}\text { AR 1961-62, page } 93 \text { before adjustment for wives' earnings } \\
\text { deficiency; income after tax from AR 1962-3, page 93, before } \\
\text { adjustment for wives' earnings deficiency. }\end{array}$ \\
\hline $1962-63$ & annual & $\begin{array}{l}180 \\
(24.2 \%)\end{array}$ & $\begin{array}{l}\text { AR 1963-64, page } 83 \text { before adjustment for wives' earnings } \\
\text { deficiency and page } 88 \text {; income after tax from page } 83 \text { after } \\
\text { adjustment for wives' earnings deficiency. }\end{array}$ \\
\hline $1963-64$ & annual & $\begin{array}{l}275 \\
(35.5 \%)\end{array}$ & $\begin{array}{l}\text { AR 1964-65, page } 82 \text { before adjustment for wives' earnings } \\
\text { deficiency and page } 87 \text {; income after tax from page } 82 \text { after } \\
\text { adjustment for wives' earnings deficiency. }\end{array}$ \\
\hline $1964-65$ & quinquennial & $\begin{array}{l}275 \\
(33.4 \%)\end{array}$ & $\begin{array}{l}\text { AR 1965-66, page } 120 \text { before adjustment for wives' earnings } \\
\text { deficiency; income after tax from pages } 97,135 \text { and } 137 \text { and } \\
\text { from IRS 1971, page } 71 \text {. }\end{array}$ \\
\hline \multirow[t]{2}{*}{$1965-66$} & annual & $\begin{array}{l}275 \\
(31.0 \%) \\
\end{array}$ & $\begin{array}{l}\text { AR 1966-67, page } 174 \text { before adjustment for wives' earnings } \\
\text { deficiency; income after tax from page } 174 \text {. }\end{array}$ \\
\hline & & & $\begin{array}{l}\text { No correction made for investment income deficiency in SPI } \\
\text { from 1966-67 }\end{array}$ \\
\hline $1966-67$ & annual & $\begin{array}{c}275 \\
(28.4 \%) \\
\end{array}$ & $\begin{array}{l}\text { AR 1967-68, page } 96 \text { before adjustment for wives' earnings } \\
\text { deficiency; income after tax from page } 73 \text {. }\end{array}$ \\
\hline $1967-68$ & annual & $\begin{array}{c}275 \\
(27.1 \%) \\
\end{array}$ & IRS 1971, page 73; income after tax from page 73. \\
\hline $1968-69$ & annual & $\begin{array}{c}275 \\
(25.3 \%) \\
\end{array}$ & IRS 1971, page 73; income after tax from page 73. \\
\hline $1969-70$ & quinquennial & $\begin{array}{c}330 \\
(28.2 \%) \\
\end{array}$ & SPI 1969-70, page 11; income after tax from page 11. \\
\hline $1970-71$ & annual & $\begin{array}{c}420 \\
(32.4 \%) \\
\end{array}$ & SPI 1970-71, page 1 ; income after tax from page 1. \\
\hline $1971-72$ & annual & $\begin{array}{c}420 \\
(29.2 \%)\end{array}$ & IRS 1974, page 42; income after tax from page 42. \\
\hline
\end{tabular}




\begin{tabular}{|c|c|c|c|}
\hline $1972-73$ & annual & $\begin{array}{l}595 \\
(36.9 \%) \\
\end{array}$ & IRS 1975, page 43; income after tax from page 43. \\
\hline 1973-74 & annual & $\begin{array}{l}595 \\
(32.0 \%) \\
\end{array}$ & IRS 1976, page 36; income after tax from page 36. \\
\hline \multirow[t]{2}{*}{$1974-75$} & annual & $\begin{array}{c}625 \\
(27.3 \%) \\
\end{array}$ & IRS 1977, page 43; income after tax from page 43. \\
\hline & & & $\begin{array}{l}\text { Data from now on relate to total income before deduction of } \\
\text { allowable expenses such as mortgage interest }\end{array}$ \\
\hline $1975-76$ & annual & $\begin{array}{l}675 \\
(24.3 \%) \\
\end{array}$ & $\begin{array}{l}\text { SPI } 1975-76 \text { and } 1976-77 \text {, page } 16 \text {; income after tax from } \\
\text { page } 16 .\end{array}$ \\
\hline $1976-77$ & annual & $\begin{array}{l}735 \\
(22.5 \%) \\
\end{array}$ & $\begin{array}{l}\text { SPI } 1975-76 \text { and 1976-77, page } 86 \text {; income after tax from } \\
\text { page } 86 .\end{array}$ \\
\hline $1977-78$ & annual & $\begin{array}{l}810 \\
(22.5 \%) \\
\end{array}$ & SPI 1977-78, page 16; income after tax from page 16. \\
\hline 1978-79 & annual & $\begin{array}{l}1,000 \\
(24.3 \%)\end{array}$ & SPI 1978-79, page 16; income after tax from page 16. \\
\hline $1979-80$ & annual & $\begin{array}{l}1,000 \\
(20.6 \%) \\
\end{array}$ & SPI 1979-80, page 20; income after tax from page 20. \\
\hline $1980-81$ & annual & $\begin{array}{l}1,350 \\
(23.8 \%) \\
\end{array}$ & $\begin{array}{l}\text { SPI 1982-83, frequencies by ranges from page } 8 \text {, page } 9 \text { for } \\
\text { after tax income, but no information available on amounts. }\end{array}$ \\
\hline $1981-82$ & annual & $\begin{array}{l}1,350 \\
(22.3 \%)\end{array}$ & $\begin{array}{l}\text { SPI } 1982-83 \text {, frequencies by ranges from page } 8 \text {, page } 9 \text { for } \\
\text { after tax income, and information on amounts by ranges } \\
\text { supplied by Inland Revenue. }\end{array}$ \\
\hline $1982-83$ & annual & $\begin{array}{l}1,550 \\
(23.3 \%)\end{array}$ & SPI 1982-83, page 10; income after tax from page 10. \\
\hline $1983-84$ & annual & $\begin{array}{l}1,750 \\
(24.7 \%) \\
\end{array}$ & SPI 1983-84, page 10; income after tax from page 10. \\
\hline $1984-85$ & annual & $\begin{array}{l}2,000 \\
(26.6 \%)\end{array}$ & SPI 1984-85, page 10; income after tax from page 10. \\
\hline $1985-86$ & annual & $\begin{array}{l}2,200 \\
(27.1 \%)\end{array}$ & IRS 1988, page 23; income after tax from page 23. \\
\hline $1986-87$ & annual & $\begin{array}{l}2,330 \\
(26.6 \%) \\
\end{array}$ & IRS 1989 , page 24; income after tax from page 24. \\
\hline $1987-88$ & annual & $\begin{array}{l}2,420 \\
(25.9 \%)\end{array}$ & IRS 1990, page 28; income after tax from page 28. \\
\hline $1988-89$ & annual & $\begin{array}{l}2,605 \\
(25.25)\end{array}$ & IRS 1991, page 25; income after tax from page 25. \\
\hline \multirow[t]{2}{*}{$1989-90$} & annual & $\begin{array}{l}2,785 \\
(24.6 \%) \\
\end{array}$ & IRS 1992, page 29; income after tax from page 29. \\
\hline & & & $\begin{array}{l}\text { Independent taxation introduced; data now relate to } \\
\text { individuals. }\end{array}$ \\
\hline $1990-91$ & annual & $\begin{array}{l}3,005 \\
(24.4 \%) \\
\end{array}$ & IRS 1993, page 34; income after tax from page 34. \\
\hline $1991-92$ & annual & $\begin{array}{l}3,295 \\
(25.3 \%) \\
\end{array}$ & IRS 1994, page 36; income after tax from page 36. \\
\hline $1992-93$ & annual & $\begin{array}{l}3,445 \\
(25.1 \%)\end{array}$ & IRS 1994, page 36; income after tax from page 36. \\
\hline 1993-94 & annual & $\begin{array}{l}3,445 \\
(24.1 \%) \\
\end{array}$ & IRS 1995, page 34; income after tax from page 34. \\
\hline 1994-95 & annual & $\begin{array}{l}3,445 \\
(23.1 \%)\end{array}$ & IRS 1996, page 35; income after tax from page 35. \\
\hline
\end{tabular}




\begin{tabular}{|l|l|l|l|}
\hline $1995-96$ & annual & $\begin{array}{l}3,525 \\
(22.3 \%)\end{array}$ & IRS 1997, page 34; income after tax from page 34. \\
\hline $1996-97$ & annual & $\begin{array}{l}3,765 \\
(22.6 \%)\end{array}$ & IRS 1998, page 34; income after tax from page 34. \\
\hline $1997-98$ & annual & $\begin{array}{l}4,045 \\
(23.2 \%)\end{array}$ & $\begin{array}{l}\text { IRS 1999, page 36 for gross income (with top range from page } \\
\text { 32); income after tax from page 32. }\end{array}$ \\
\hline $1998-99$ & annual & $\begin{array}{l}4,195 \\
(22.9 \%)\end{array}$ & $\begin{array}{l}\text { IRS 2000, page 41 for gross income (with top range from page } \\
\text { 37); income after tax from page 37. }\end{array}$ \\
\hline $1999-2000$ & annual & 4,335 & $\begin{array}{l}\text { IR website, pi t05 1 for gross income; pi t03 1 for after tax } \\
\text { distribution. }\end{array}$ \\
\hline
\end{tabular}




\section{Appendix C Total Population and Income Data for the Netherlands}

The initial total number of tax units is calculated from CBS population statistics by age and gender (Maandstatistiek Bevolking and data specially provided by CBS from its archives) for the total population aged 15 and over. From this has been subtracted the minimum of the number of men and women married. For 1950-1999 this is obtained directly from the above CBS population statistics. For 1920 and 1930 it is obtained from the census data (specially provided by CBS) and for other years from 1914 to 1946 it is obtained by linear inter- and extra-polation of the percentages of married persons for 1920 and 1930 applying this to the absolute numbers from the population statistics.

Table $\mathrm{C} 1$ shows the resulting figures in the first column. The third and fourth columns show the reported totals in the tax statistics. As may be seen, over time the total has converged towards the constructed total- see Figure C1. By 1999 the IPO total was fairly stable at around $95 \%$ of the constructed total, and the coverage was believed to be complete. We have therefore taken the IPO totals when presenting these estimates, and a fixed proportion (95\%) of the constructed total for all earlier years. The difference between the reported figure and the $95 \%$ figure (the estimated number of "non-filers") is shown in the final column.

The starting point for the total income series is provided by the tax statistics. As explained in the text, for the period from 1977 we take the IPO totals, shown in column 3 of Table C2. For the period 1941 and earlier, we take the totals reported in JC/SR (see Table A1) and add the estimated income of those below the tax threshold, shown in column 4. The sources of the latter are 19141920 from CBS (1941), page 14, 1921-1939 from CBS (1948), page 21, 1941 from CBS (19), page 41. The missing income is divided by the estimated number of non-filers (column 5 in Table $\mathrm{C} 1)$ to give the mean income of non-filers. This is expressed in column 4 as a percentage of the mean income of filers (obtained by dividing column 1 in Table $\mathrm{C} 2$ by column 3 in Table C1). This percentage is close to $20 \%$ in the 1930 s, and this proportion is assumed to apply in the period 1946-1975. Multiplying the resulting mean income by the estimated number of non-filers yields the estimates in column 6 of Table C2. For 1968 and 1969, where the data only cover people with incomes above 15,000 guilders, a percentage of the national accounts figure (see below) has been assumed.

The resulting estimates may be compared with the personal sector gross income totals in the national accounts. These figures are close to those for the "current receipts of households and nonprofit institutions" contained in the United Nations Yearbook of National Accounts Statistics. The 
sources are 1914-20 from CBS (1941), page 14, 1921-39 from CBS (1948), page 21, 1941 from CBS (1950), page 41, 1946 from CBS (1949), page 7, 1950-59 from CBS (1961), page 70, 1960-1 from CBS (1973), page 109, 1962-74 from CBS (1975), page 112, 1975. Data for 19771999 are from Central Planning Bureau (1999) that was the last publication presenting the data according to the pre-1993 SNA, which serves to improve consistency with the previous data. CPB data follow CBS as closely as possible and offer the advantage of including the data for 1977-1986 that have been revised in 1995. Unfortunately, it implies that the data for 1998 and 1999 are provisional. Thus the series in column 8 of Table $\mathrm{C} 2$ comes as close as possible to standardisation on a pre-1977 basis, but a precise linking for that year has not been pursued here as the tax-based income data changed at the same time with the use of IPO as a source. The totals used here are shown as a percentage of the national accounts personal income total in Figure D1, discussed in Appendix D in conjunction with the corresponding figures for the UK.

The series for disposable income is obtained by subtracting from the gross income totals described above the difference between the gross and disposable income in the IenV estimates, shown in the penultimate column of Table $\mathrm{C} 2$. The final column shows the IPO totals for disposable income. 
Table C1 Netherlands Population Totals (thousands)
1
2
3
4
5

Tax Units calculated from popn $15+$ minus married

Difference Reported Numbers between column $95 \%$ of column taxpayers in JC reported in 2 and reported 1 and SR lenV and IPO numbers

\begin{tabular}{|c|c|c|c|c|}
\hline 1914 & 3,109 & 2,954 & 679 & 2,275 \\
\hline 1915 & 3,159 & 3,001 & 758 & 2,243 \\
\hline 1916 & 3,209 & 3,048 & 876 & 2,172 \\
\hline 1917 & 3,259 & 3,096 & 897 & 2,199 \\
\hline 1918 & 3,297 & 3,132 & 966 & 2,166 \\
\hline 1919 & 3,348 & 3,181 & 1,368 & 1,813 \\
\hline 1920 & 3,400 & 3,230 & 1,638 & 1,592 \\
\hline 1921 & 3,456 & 3,283 & 1,690 & 1,593 \\
\hline 1922 & 3,509 & 3,334 & 1,632 & 1,702 \\
\hline 1923 & 3,570 & 3,391 & 1,625 & 1,766 \\
\hline 1924 & 3,631 & 3,450 & 1,658 & 1,792 \\
\hline 1925 & 3,690 & 3,506 & 1,694 & 1,812 \\
\hline 1926 & 3,747 & 3,560 & 1,719 & 1,841 \\
\hline 1927 & 3,808 & 3,617 & 1,746 & 1,871 \\
\hline 1928 & 3,871 & 3,677 & 1,831 & 1,846 \\
\hline 1929 & 3,929 & 3,733 & 1,893 & 1,840 \\
\hline 1930 & 3,987 & 3,788 & 1,867 & 1,921 \\
\hline 1931 & 4,062 & 3,859 & 1,668 & 2,191 \\
\hline 1932 & 4,130 & 3,923 & 1,485 & 2,438 \\
\hline 1933 & 4,187 & 3,978 & 1,445 & 2,533 \\
\hline 1934 & 4,245 & 4,033 & 1,355 & 2,678 \\
\hline 1935 & 4,308 & 4,093 & 1,285 & 2,808 \\
\hline 1936 & 4,368 & 4,149 & 1,304 & 2,845 \\
\hline 1937 & 4,426 & 4,204 & 1,364 & 2,840 \\
\hline 1938 & 4,485 & 4,261 & 1,409 & 2,852 \\
\hline 1939 & 4,536 & 4,309 & 1,536 & 2,773 \\
\hline \multicolumn{5}{|l|}{1940} \\
\hline 1941 & 4,637 & 4,405 & 2,838 & 1,567 \\
\hline \multicolumn{5}{|l|}{1942} \\
\hline \multicolumn{5}{|l|}{1943} \\
\hline \multicolumn{5}{|l|}{1944} \\
\hline \multicolumn{5}{|l|}{1945} \\
\hline 1946 & 4,890 & 4,646 & 3,605 & 1,041 \\
\hline 1947 & 4,925 & 4,679 & & \\
\hline 1948 & 4,965 & 4,717 & & \\
\hline 1949 & 4,994 & 4,745 & & \\
\hline 1950 & 5,041 & 4,789 & & 795 \\
\hline
\end{tabular}




\begin{tabular}{|c|c|c|c|c|}
\hline 1951 & 5,071 & 4,817 & & \\
\hline 1952 & 5,090 & 4,836 & 4,012 & 824 \\
\hline 1953 & 5,123 & 4,867 & 4,079 & 788 \\
\hline 1954 & 5,164 & 4,906 & 4,208 & 698 \\
\hline 1955 & 5,213 & 4,952 & 4,280 & 672 \\
\hline 1956 & 5,253 & 4,990 & & \\
\hline 1957 & 5,301 & 5,036 & 4,566 & 470 \\
\hline 1958 & 5,376 & 5,107 & 4,607 & 500 \\
\hline 1959 & 5,446 & 5,174 & 4,689 & 485 \\
\hline 1960 & 5,505 & 5,229 & 4,803 & 426 \\
\hline 1961 & 5,646 & 5,364 & & \\
\hline 1962 & 5,776 & 5,487 & 5,099 & 388 \\
\hline 1963 & 5,880 & 5,586 & 5,285 & 301 \\
\hline 1964 & 5,966 & 5,667 & 5,310 & 357 \\
\hline 1965 & 6,066 & 5,763 & 5,658 & 105 \\
\hline 1966 & 6,151 & 5,843 & 5,776 & 67 \\
\hline 1967 & 6,210 & 5,900 & 5,735 & 165 \\
\hline 1968 & 6,278 & 5,964 & & \\
\hline 1969 & 6,359 & 6,041 & & \\
\hline 1970 & 6,442 & 6,120 & 5,631 & 489 \\
\hline 1971 & 6,524 & 6,198 & & \\
\hline 1972 & 6,604 & 6,274 & 6,380 & \\
\hline 1973 & 6,702 & 6,367 & 6,491 & \\
\hline 1974 & 6,812 & 6,471 & & \\
\hline 1975 & 6,950 & 6,603 & 5,680 & 923 \\
\hline 1976 & 7,070 & 6,716 & & \\
\hline 1977 & 7,198 & 6,838 & 6,352 & 486 \\
\hline 1978 & 7,336 & 6,969 & & \\
\hline 1979 & 7,492 & 7,117 & 6,639 & 478 \\
\hline 1980 & 7,642 & 7,260 & & \\
\hline 1981 & 7,778 & 7,389 & & \\
\hline 1982 & 7,892 & 7,497 & & \\
\hline 1983 & 8,028 & 7,626 & & \\
\hline 1984 & 8,173 & 7,764 & & \\
\hline 1985 & 8,315 & 7,899 & 7,461 & 438 \\
\hline 1986 & 8,430 & 8,008 & & \\
\hline 1987 & 8,552 & 8,124 & & \\
\hline 1988 & 8,641 & 8,209 & & \\
\hline 1989 & 8,661 & 8,228 & 7,962 & 266 \\
\hline 1990 & 8,780 & 8,341 & 8,105 & 236 \\
\hline 1991 & 8,852 & 8,410 & 8,222 & 188 \\
\hline 1992 & 8,921 & 8,475 & 8,309 & 166 \\
\hline 1993 & 8,992 & 8,542 & 8,401 & 141 \\
\hline 1994 & 9,049 & 8,597 & 8,484 & 113 \\
\hline 1995 & 9,119 & 8,663 & 8,538 & 125 \\
\hline 1996 & 9,185 & 8,726 & 8,614 & 112 \\
\hline 1997 & 9,252 & 8,789 & 8,698 & 91 \\
\hline 1998 & 9,319 & 8,853 & 8,758 & 95 \\
\hline 1999 & 9,386 & 8,917 & 8,852 & 65 \\
\hline
\end{tabular}



1
23
4
56
7
8
9
10
11

Table C2 Reference Income Totals in Netherlands (million guilders)

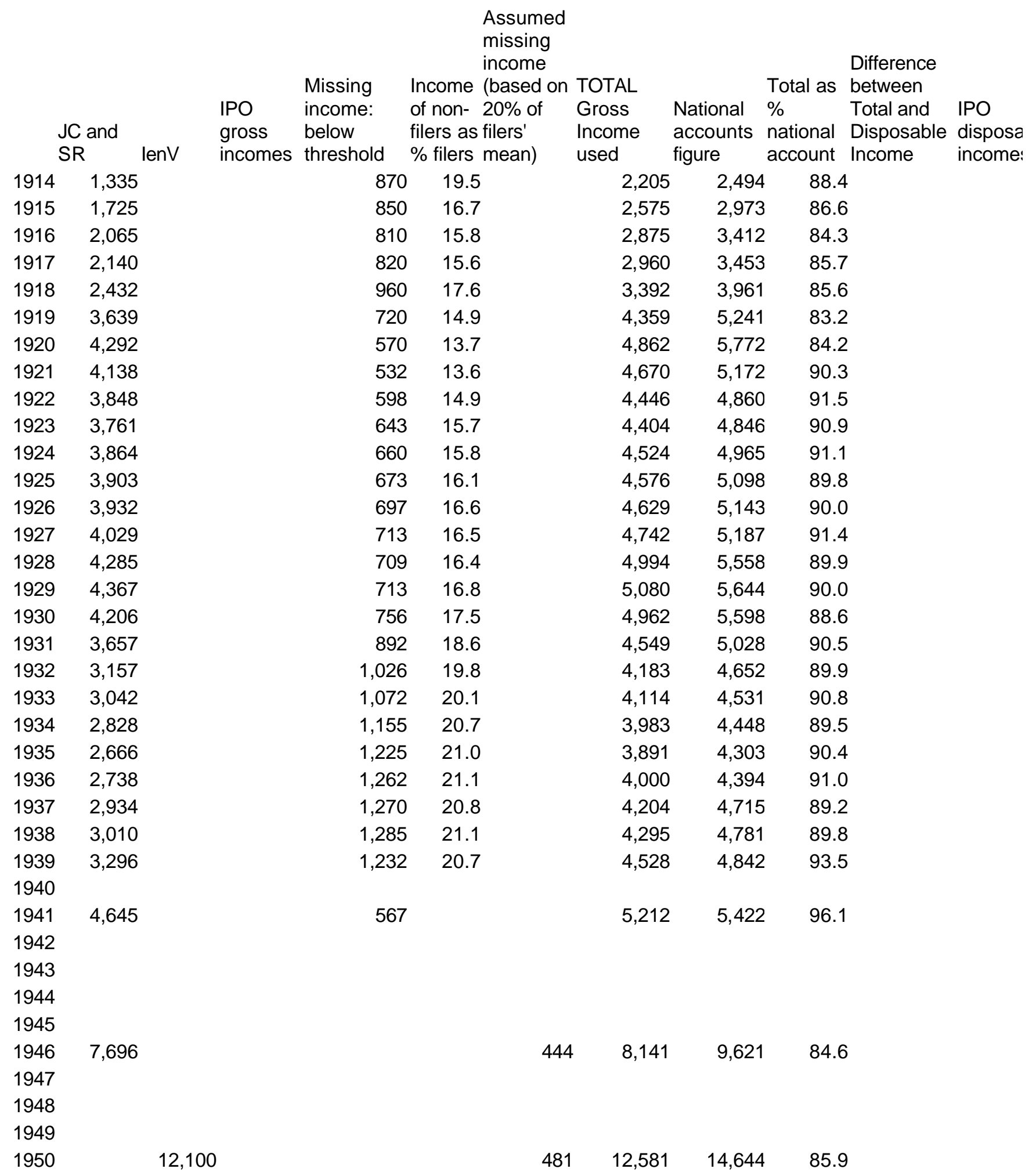


1951

1952

1953

1954

1955

1956

1957

1958

1959

1960

1961

1962

1963

1964

1965

1966

1967

1968

1969

1970

1971

1972

1973

1974

1975

1976

1977

1978

1979

1980

1981

1982

1983

1984

1985

1986

1987

1988

1989

1990

1991

1992

1993

1994

1995

1996

1997

1998

1999

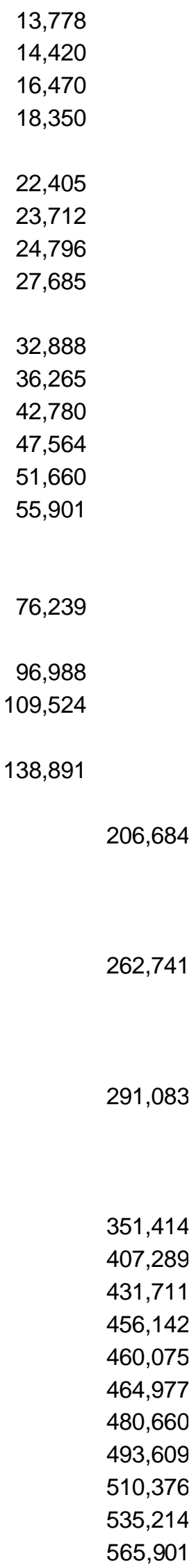

\begin{tabular}{|c|c|c|c|c|c|}
\hline 566 & 14,344 & 17,374 & 82.6 & & \\
\hline 557 & 14,977 & 18,684 & 80.2 & & \\
\hline 546 & 17,016 & 21,218 & 80.2 & & \\
\hline 577 & 18,927 & 23,957 & 79.0 & & \\
\hline 461 & 22,866 & 29,136 & 78.5 & & \\
\hline 515 & 24,227 & 30,482 & 79.5 & & \\
\hline 513 & 25,309 & 31,930 & 79.3 & 3,972 & \\
\hline 491 & 28,176 & 35,327 & 79.8 & & \\
\hline 500 & 33,388 & 40,809 & 81.8 & 4,934 & \\
\hline 412 & 36,677 & 45,767 & 80.1 & & \\
\hline 576 & 43,356 & 54,062 & 80.2 & 6,819 & \\
\hline 176 & 47,740 & 61,015 & 78.2 & & \\
\hline 120 & 51,780 & 67,279 & 77.0 & 8,687 & \\
\hline \multirow[t]{3}{*}{321} & 56,222 & 74,345 & 75.6 & 9,309 & \\
\hline & 61,361 & 81,815 & 75 & & \\
\hline & 69,465 & 93,871 & 74 & & \\
\hline 1,324 & 77,562 & 105,714 & 73.4 & 10,229 & \\
\hline 0 & 96,988 & 137,890 & 70.3 & & \\
\hline 0 & 109,524 & 157,140 & 69.7 & 15,712 & \\
\hline \multirow[t]{24}{*}{4,512} & 143,403 & 206,870 & 69.3 & 23,255 & \\
\hline & 206,684 & 272,610 & 75.8 & & 134 \\
\hline & & 295,201 & & & \\
\hline & & 317,822 & & & \\
\hline & & 340,165 & & & \\
\hline & 262,741 & 355,441 & 73.9 & & 171, \\
\hline & & 373,481 & & & \\
\hline & & 383,369 & & & \\
\hline & & 389,548 & & & \\
\hline & 291,083 & 403,856 & 72.1 & & 192 \\
\hline & & 420,582 & & & \\
\hline & & 435,608 & & & \\
\hline & & 447,388 & & & \\
\hline & 351,414 & 466,034 & 75.4 & & 231, \\
\hline & 407,289 & 501,681 & 81.2 & & 251, \\
\hline & 431,711 & 529,167 & 81.6 & & 264 \\
\hline & 456,142 & 560,641 & 81.4 & & 274 \\
\hline & 460,075 & 575,904 & 79.9 & & 281, \\
\hline & 464,977 & 594,675 & 78.2 & & 292 \\
\hline & 480,660 & 608,087 & 79.0 & & 305 \\
\hline & 493,609 & 627,018 & 78.7 & & 314 \\
\hline & 510,376 & 660,097 & 77.3 & & 328 \\
\hline & 535,214 & 690,592 & 77.5 & & 343 \\
\hline & 565,901 & 725,927 & 78.0 & & 358, \\
\hline
\end{tabular}




\section{Appendix D Total Population and Income Data for the UK}

The derivation of the tax unit control totals for the UK start is described in Atkinson (2002), Appendix A. The only difference here is that from 1990, following the introduction of independent taxation for husbands and wives, the total used is that for all individuals aged 15 and over. The figures used are (millions):

$\begin{array}{llllll}1990 & 46.347 & 1991 & 46.455 & 1992 & 46.675 \\ 1993 & 46.894 & 1994 & 47.043 & 1995 & 47.249 \\ 1996 & 46.802 & 1997 & 46.919 & 1998 & 47.071 \\ 1999 & 47.259 & & & & \end{array}$

The sources are Population Trends, Winter 2002, page 47, for 1986, 1991, 1996-9, Population Trends, Spring 2002, page 59, page for 1995, Population Trends, Spring 2001, page 59, for 1993 and 1994. The figures for 1990 and 1992 are linearly interpolated using the figures for 1986 and 1991 and 1991 and 1993, respectively.

The construction of the total personal income (before tax) series differs from that in Atkinson (2002), although it uses many of the same sources, notably Feinstein (1972), and the national accounts, published in the "Blue Book", known for much of the period as National Income and Expenditure, and referred to here as NIE. The aim is to arrive at a total formed by adding to the income of filers an estimate of the income, defined in the same way, of non-filers, comparable with that used in the estimates for the Netherlands. As noted in the text, the estimates in Atkinson (2002) correspond to a more extensive definition; based on the estimates of "allocated total income" made by the Central Statistical Office (CSO), which includes non-taxable income in kind and non-taxable social security benefits, of which the most important in the 1970s were social assistance, sickness/industrial injury benefits, NI disability pensions, invalidity pension and NI unemployment benefit (Ramprakash, 1972, page 82). (At that time, family allowances were taxable; child benefit, introduced in 1978, is tax-free.) In 1972, the total income covered by the Survey of Personal Incomes (SPI) was $£ 40,778$ million, to which the CSO estimated $£ 2,538$ million should be added for the taxable income of non-filers and £2,448 million for non-taxable income (Ramprakash, 1972, page 92). Here we make in principle the first, but not the second, of these additions.

The resulting totals are shown in Tables D1 for the period prior to 1945 and D2 for the period from 1945. The methods are described below. For the years 1969 to 1975 we may compare them with the CSO estimates of added income. In 4 of the 7 cases, the estimates made here are below those of the CSO, and in 3 above. The mean of the CSO estimates is $3.6 \%$ higher. Given that we were limited to materials available over throughout the 50-year period, this degree of 
agreement seems reassuring.

\section{Adjustments from 1945}

The starting point is (column 1) the total income reported in the SPI, which is "total net income" until 1974 and then "total income", with the sources given in Table B2. The 1980 figure is interpolated logarithmically using personal sector gross income in 1979 and 1981 . Where the SPI totals are not available, we take (column 2) the "actual income" reported by the Inland Revenue less estimated undistributed profits. The sources are: 1945-51 from AR1952-3, page 46; 1952-60 from AR 1961-2, page 43; 1961-2 from AR 1965-6, page 50. Undistributed profits are taken as the average of those in year t and year (t-1) from Feinstein (1972), p T30 (except years 1944 and 1945 - see below).

To this must be added the adjustment for non-filers. The CSO estimates for 1972 show a total of $£ 100$ million adjustment for the under-coverage of earned income. This is less than a quarter of the difference between the SPI total and the national accounts figure for wages, salaries and pay of HM Forces, and is only $0.3 \%$ of the latter figure. It might be thought that the adjustment should be higher in the earlier post-war years, but the totals for 1949-50, 1954-5 and 1959-60 suggest that the SPI figure is within 5\% of the national accounts figure, and the majority of that difference is likely to be attributable to under-recording of those covered. In view of this, we make no adjustment for earned incomes post- 1945 .

The elements allowed for in Table D2 are therefore (a) NI retirement and widows' pensions and (b) occupational pensions, which together accounted for $94 \%$ of the adjustment for undercoverage in 1972/73. The two items are treated separately for all years where the SPI totals distinguish them: 1962-1998, except 1980 and 1981. The adjustments are obtained by subtracting the totals recorded in the SPI from control totals. The sources of the control totals are:

National Insurance retirement pensions and widows' pensions: 1945 from Minister of Reconstruction (1944), page 52; 1946 and 1947 from National Income and Expenditure (NIE) 1946-9, page 43; 1948-1957 from NIE 1958, page 43; 1958-63 from NIE 1964, page 43; $1964-$ 68 from NIE 1969, page 49; 1969-1977 from NIE 1967-77, page 59; 1978-85 from NIE 1987, page 54; 1986-1996 from NIE 1997, page 102; 1997-2000 from NIE 2001, page 201. The figures were converted to a tax year basis by taking 0.75 of the figure for year $t$ and 0.25 of the figure for year $(\mathrm{t}+1)$.

Occupational pensions: Direct estimates of the total paid in occupational pensions are only available for a number of years. The NIE total refers to "pensions and other benefits from life 
assurance and superannuation schemes", which includes items such as lump-sum payments on retirement or death, and refunds of contributions, which are not treated as part of taxable income. This total cannot therefore be used unadjusted. For the 1970s the CSO made estimates of the amounts of occupational pensions. The sources are (for tax years): 1972-3 from NIE 1975, page 109; 1973-4 from NIE 1976, page 111; 1974-5 from NIE 1977, page 115; 1975-6 from NIE 1978, page 119; 1976-7 from NIE 1979, page 115; 1977-8 from NIE 1980, page 110. The new system of national accounts SNA 1993 allows the total pensions in payment to be distinguished: sources (calendar years) 1990 and 1991 from NIE 1999, page 209, 1993-2000 from NIE 2001, page 223. The calendar year figures were converted to a tax year basis by taking 0.75 of the figure for year $t$ and 0.25 of the figure for year $(t+1)$. Inspection of these figures showed that pensions in payment were around 55\% of the national accounts total in the 1970s but had risen to around $70 \%$ in 1990, as would have been expected as pension schemes matured. A proportion of $55 \%$ was taken prior to 1978 and interpolated linearly between 55 and $70 \%$ between 1978 and 1990. The actual CSO figures were used for 1991-1998.

Remaining Years: The SPI years 1949, 1954 and 1959 have totals for all pensions, and these were used with the sum of the control totals described above. The figures for 1945-1948 were extrapolated backwards from 1949 using the total for NI retirement and widows' pensions. The adjustments in the SPI years were expressed as a percentage of the total NI and occupational pensions, and the percentages interpolated to give figures for 1950 to 1953,1955 to 1958 and 1960 and 1961. The figures for 1980 and 1981, and for 1999, were interpolated using the total for NI retirement and widows' pensions.

It is interesting to compare the resulting totals with total personal sector gross income. The adjusted total shows a distinct decline, from a figure in excess of $80 \%$ at the start of the 1950 s to below 75\% in the second half of the 1990s. Compared with the totals in Atkinson (2002), those employed here are smaller, as would be expected with a less extensive definition, by an amount which is around 5\% in the first part of the post-war period and which rises to around $10 \%$ in the second half, although there is considerable variation and in some years the difference is $15 \%$.

\section{Adjustments Prior to 1945}

The estimates for the period prior to 1945 are set out in Table D2. Figures for 1920 and earlier include what is now the Republic of Ireland. The starting point is the total "actual" income assessed by the Inland Revenue for income tax purposes. It should be noted that, although the UK income tax administrative data at this time provided no distributional information, the totals can be 
used. The total in column 1 refers to gross income assessed less (a) the incomes of those below the exemption limit included in the assessments, (b) the income of charities, colleges and other non-profit institutions, (c) dividends paid to non-residents, and (d) allowances for depreciation. From this we subtract that part of profits not distributed by companies (column 3) and add:

wages not assessed (column 4-column 2)

salaries below the exemption level (column 5)

self-employment income below the exemption level (column 6)

dividends and other capital income below the exemption level (column 7)

contributory NI retirement and widows' pensions.

According to Bowley and Stamp, the income reviewed for the fiscal year commencing in April of year t may be treated as "virtually identical" with income for the calendar year t: "it would be identical for Schedules A and B, and is closely similar for Schedules C and E" (1927, page 16). The main difference concerns Schedule D, which was then assessed on a basis of an average of the preceding 3 or 5 years. This latter treatment was changed to a one-year lag in 1926 (AR 1927-28, page 56). According to Clark, "the actual income for the calendar year 1928 [is] the sum of the assessments under Schedules A, B and C for 1928-9 and under Schedules D and E for 1929-30" (1932, page 32). We cannot here make a separate adjustment for the latter schedules, except when subtracting undistributed profits.

Column 1. The sources are (years refer to income tax years commencing in April) 1908 from AR 1913-4, page 100; 1909-1918 from AR 1919-20, page 62; 1919-1923 from AR 1927-8, page 73; 1924-28 from AR 1933-4, page 63; 1929-35 from AR 1938-39, page 56; 1936-1942 from AR 1945-6, page 52; 1945 from AR 1946-47, page 65; 1943 and 1944 linearly interpolated.

Column 2. The wages included in the tax assessments are shown for most years in the sources given for column 1. (It should be noted that a distinction is drawn between "wages" and "salaries".) 194345 calculated as same \% of column 1 as 1942 . Wages assessed prior to 1918 interpolated using the 1911 figure from Feinstein (1972, page 173), and information on the exemption limit. Where the exemption limit was reduced by a factor $(1+\mathrm{x})$, the amount of wages assessed is assumed to rise according to the formula $(1+\mathrm{x})^{4}$.

Column 3. Post-1927 figure for year (t-1), previously average of years (t-1) and year (t-2). 19201938 from Feinstein, 1972, page T30; 1912 from Colwyn Committee, 1927, page 18; other years prior to 1920 interpolated using gross trading profits of companies and income from selfemployment (undivided total) from Feinstein, 1972, page T5; 1939-1944 taken as equal to the 


\section{8 figure.}

Column 4. Total wages from Feinstein, 1972, page T55. The figures is reduced by $5 \%$ to allow for the fact that some wage income would have escaped the attention of the Inland Revenue. The percentage deducted is a matter of judgment, but seems reasonable in the light of the post-1944 figures after the introduction of PAYE (collection at source).

Columns 5-7. The pre-1918 figures for salaries and self-employment income are based on the estimates for 1911 given by Bowley (1937, page 81). The total of $£ 264$ million for salaries and selfemployment earnings is close to the figure of $£ 285$ million given by Cannan et al (1910, page 64). They are extrapolated backwards to 1907 and forwards to 1917 using the series for salaries from Feinstein (1972, page T55) and self employment income from Feinstein (1972, pages T5 and T6), reduced when the exemption limit changed using exponent of 3 for salaries and 1.5 for self employment income, allowing a one year lag when the exemption limit was lowered from $£ 160$ a year to $£ 130$ in 1915 - 16 . The figure of $£ 50$ million for "Dividends and other capital income" below the tax threshold is taken from Bowley (1937, page 81). It is identical to the figure given by Cannan et al (1910, page 64) for 1911, and it is assumed to apply to all pre-First World War years. Column 8. The figures relate to the contributory pensions first introduced in 1926. Figures up to 1934 from Clark (1937, page 141); 1935-38 from Hansard 14 December 1939, column 1316; 1939-44 interpolated from the figure of $£ 95$ million in Minister of Reconstruction (1944, page 52).

It is again interesting to compare the resulting totals with total personal sector gross income. In Atkinson (2002), the totals were taken as $88.5 \%$ of personal sector gross income prior to 1938 . The new totals calculated here are higher than this proportion in the period before the First World War, by some $5 \%$ on average. They are then below $88.5 \%$ for the rest of the period, as would be expected with a less extensive income concept. For 1938 , the total is $£ 4,320$ million, compared with the CSO total for allocated income of $£ 4,463$ million (i.e. about $3 \%$ less). If the new figures are more consistent over time, then Atkinson (2002) may have overstated the downward trend in top income shares.

The figures for the whole period are graphed in Figure D1, together with those for the Netherlands. For the two war periods, there is a noticeable divergence, which reinforces grounds for treating these figures with caution. In the 1920s and 1950s the percentages seem broadly similar. After some divergence during the late 1960s and early 1970s, the use of IPO since 1977 has brought back broad similarity, including the direction of the changes up and downwards.

\section{Net of Tax Incomes}


From the totals for gross income are subtracted the figures for total income tax recorded in the sources listed in Table B2. 
Table D1 Derivation of Control Totals ( $£$ million) for Income in UK applied to tax year data 1945/61999/2000

\begin{tabular}{|c|c|c|c|c|c|c|c|c|c|c|}
\hline & 1 & 2 & 3 & 4 & 5 & 6 & 7 & 8 & 9 & 10 \\
\hline $\begin{array}{l}\text { Calendar } \\
\text { year (tax } \\
\text { year } \\
\text { starting } \\
\text { in April) }\end{array}$ & $\begin{array}{l}\text { SPI } \\
\text { income }\end{array}$ & $\begin{array}{l}\text { Returned } \\
\text { income (= IR } \\
\text { actual } \\
\text { income - } \\
\text { undistributed } \\
\text { profits) }\end{array}$ & $\begin{array}{l}\text { Non-filers' } \\
\mathrm{NI} \\
\text { retirement } \\
\text { and } \\
\text { widows' } \\
\text { pensions }\end{array}$ & $\begin{array}{l}\text { Non-filers' } \\
\text { occupational } \\
\text { pensions }\end{array}$ & $\begin{array}{l}\text { All } \\
\text { pensions } \\
\text { (cols } 3 \\
\text { I and } 4 \\
\text { combined) }\end{array}$ & $\begin{array}{l}\text { Total } \\
\text { added } \\
\text { (col 3+ } \\
\text { col 4) or } \\
\text { col } 5\end{array}$ & $\begin{array}{l}\text { CSO } \\
\text { estimate } \\
\text { of added } \\
\text { income }\end{array}$ & $\begin{array}{l}\text { ADJUSTED } \\
\text { Total } \\
\text { income (col } \\
1 \text { or } 2+\text { col } \\
6 \text { ) }\end{array}$ & $\begin{array}{l}\text { ADJUSTED } \\
\text { Total as \% } \\
\text { Personal } \\
\text { sector gross } \\
\text { income }\end{array}$ & $\begin{array}{l}\text { ADJUSTED } \\
\text { Total as \% } \\
\text { (Personal } \\
\text { sector gross } \\
\text { income - } \\
\text { Transfers) }\end{array}$ \\
\hline 1945 & & 6,379 & & & 123 & & & 6,502 & 74.50 & 78.26 \\
\hline 1946 & & 6,767 & & & 149 & & & 6,916 & 78.20 & 84.62 \\
\hline 1947 & & 7,367 & & & 307 & & & 7,674 & 81.27 & 87.60 \\
\hline 1948 & & 7,917 & & & 359 & & & 8,276 & 82.92 & 89.22 \\
\hline 1949 & 8,359 & 8,280 & & & 371 & & & 8,730 & 82.74 & 89.02 \\
\hline 1950 & & 8,469 & & & 370 & & & 8,839 & 79.98 & 85.85 \\
\hline 1951 & & 9,468 & & & 377 & & & 9,844 & 82.15 & 87.91 \\
\hline 1952 & & 10,043 & & & 394 & & & 10,437 & 81.63 & 87.89 \\
\hline 1953 & & 10,693 & & & 397 & & & 11,090 & 81.70 & 88.21 \\
\hline 1954 & 11,410 & 11,507 & & & 395 & & & 11,805 & 82.31 & 88.62 \\
\hline 1955 & & 12,432 & & & 442 & & & 12,874 & 82.76 & 89.16 \\
\hline 1956 & & 13,482 & & & 472 & & & 13,954 & 83.55 & 89.98 \\
\hline 1957 & & 13,983 & & & 512 & & & 14,495 & 82.36 & 88.67 \\
\hline 1958 & & 14,381 & & & 597 & & & 14,978 & 80.60 & 87.60 \\
\hline 1959 & 15,391 & 15,014 & & & 628 & & & 16,019 & 81.38 & 88.76 \\
\hline 1960 & & 16,354 & & & 656 & & & 17,010 & 80.21 & 87.00 \\
\hline 1961 & & 18,178 & & & 716 & & & 18,894 & 82.36 & 89.40 \\
\hline 1962 & 18,978 & 18,862 & 598 & 160 & & & & 19,736 & 81.69 & 89.00 \\
\hline 1963 & 19,601 & & 682 & 163 & & & & 20,446 & 79.86 & 87.51 \\
\hline 1964 & 21,206 & & 773 & 192 & & & & 22,171 & 80.17 & 87.69 \\
\hline 1965 & 23,166 & & 851 & 208 & & 1,0 & & 24,225 & 80.61 & 88.67 \\
\hline 1966 & 24,070 & & 919 & 262 & & 1,1 & & 25,251 & 78.44 & 85.99 \\
\hline
\end{tabular}




\begin{tabular}{|c|c|c|c|c|c|c|c|c|c|}
\hline 1967 & 25,272 & 971 & 325 & & 1,296 & & 26,568 & 78.51 & 86.68 \\
\hline 1968 & 27,200 & 1,053 & 346 & & 1,399 & & 28,599 & 78.43 & 87.23 \\
\hline 1969 & 29,344 & 1,115 & 439 & & 1,554 & 1,328 & 30,898 & 78.74 & 87.52 \\
\hline 1970 & 33,005 & 1,264 & 471 & & 1,735 & 1,757 & 34,740 & 80.01 & 88.88 \\
\hline 1971 & 35,600 & 1,330 & 471 & & 1,800 & 2,094 & 37,400 & 78.19 & 86.87 \\
\hline 1972 & 39,764 & 1,731 & 560 & & 2,291 & 2,448 & 42,055 & 77.16 & 86.43 \\
\hline 1973 & 45,907 & 2,024 & 725 & & 2,748 & 2,531 & 48,655 & 76.58 & 85.18 \\
\hline 1974 & 57,339 & 2,489 & 780 & & 3,269 & 3,149 & 60,608 & 79.53 & 88.69 \\
\hline 1975 & 72,196 & 2,944 & 658 & & 3,602 & 4,310 & 75,798 & 78.45 & 87.68 \\
\hline 1976 & 83,139 & 3,139 & 561 & & 3,700 & & 86,839 & 77.55 & 87.45 \\
\hline 1977 & 91,198 & 3,896 & 494 & & 4,390 & & 95,588 & 76.81 & 87.32 \\
\hline 1978 & 104,580 & 4,417 & 619 & & 5,035 & & 109,615 & 76.41 & 87.36 \\
\hline 1979 & 123,252 & 4,867 & 904 & & 5,770 & & 129,022 & 75.97 & 86.71 \\
\hline 1980 & 141,242 & & & 6,845 & 6,845 & & 148,087 & 73.70 & 84.40 \\
\hline 1981 & 151,633 & & & 7,910 & 7,910 & & 159,543 & 71.65 & 83.36 \\
\hline 1982 & 165,860 & 6,780 & 2,701 & & 9,481 & & 175,341 & 72.51 & 85.45 \\
\hline 1983 & 178,045 & 7,316 & 3,211 & & 10,527 & & 188,572 & 72.28 & 85.39 \\
\hline 1984 & 191,560 & 8,021 & 3,957 & & 11,978 & & 203,538 & 72.07 & 85.14 \\
\hline 1985 & 218,910 & 8,569 & 5,483 & & 14,052 & & 232,962 & 75.86 & 89.66 \\
\hline 1986 & 240,573 & 10,112 & 6,811 & & 16,923 & & 257,496 & 77.30 & 91.38 \\
\hline 1987 & 261,336 & 10,443 & 9,170 & & 19,613 & & 280,949 & 78.17 & 91.58 \\
\hline 1988 & 294,000 & 10,808 & 9,310 & & 20,118 & & 314,118 & 78.42 & 90.66 \\
\hline 1989 & 332,250 & 11,346 & 13,092 & & 24,438 & & 356,688 & 80.79 & 92.54 \\
\hline 1990 & 369,330 & 11,965 & 13,928 & & 25,894 & & 395,224 & 81.35 & 93.04 \\
\hline 1991 & 384,470 & 13,078 & 15,655 & & 28,734 & & 413,204 & 79.94 & 92.76 \\
\hline 1992 & 382,540 & 15,518 & 18,854 & & 34,372 & & 416,912 & 76.05 & 89.48 \\
\hline 1993 & 382,200 & 16,275 & 19,194 & & 35,468 & & 417,668 & 72.89 & 86.67 \\
\hline 1994 & 394,940 & 16,010 & 20,352 & & 36,362 & & 431,302 & 72.01 & 85.65 \\
\hline 1995 & 414,980 & 15,621 & 22,202 & & 37,823 & & 452,803 & 71.18 & 84.31 \\
\hline 1996 & 434,820 & 16,517 & 25,142 & & 41,659 & & 476,479 & 70.86 & 83.63 \\
\hline 1997 & 469,700 & 17,100 & 27,929 & & 45,029 & & 514,729 & 72.67 & 84.93 \\
\hline
\end{tabular}


$1998 \quad 507,010$

1999527,400
16,006

28,741

47,016

44,747

47,016
551,757

574,416
74.15

73.31

86.09

84.83 
Table D2 Derivation of Control Totals ( $£$ million) for Income in UK 1907-1944

Column 1

$$
23
$$

4

5

6

7

89

10

\begin{tabular}{|c|c|c|c|c|c|c|c|c|c|c|c|}
\hline $\begin{array}{l}\text { Calendar } \\
\text { year (tax } \\
\text { year } \\
\text { starting } \\
\text { in April) }\end{array}$ & $\begin{array}{l}\text { Assessed } \\
\text { income inc } \\
\text { wages }\end{array}$ & $\begin{array}{l}\text { Wages } \\
\text { assessed }\end{array}$ & $\begin{array}{l}\text { Undistributed } \\
\text { profits }\end{array}$ & Wages & $\begin{array}{l}\text { Salaries } \\
\text { below } \\
\text { exemption } \\
\text { level }\end{array}$ & $\begin{array}{l}\text { Self } \\
\text { employment } \\
\text { income } \\
\text { below } \\
\text { exemption } \\
\text { level }\end{array}$ & $\begin{array}{l}\text { Dividends } \\
\text { below } \\
\text { exemption } \\
\text { level }\end{array}$ & $\begin{array}{l}\mathrm{NI} \\
\text { retirement } \\
\text { and } \\
\text { widows' } \\
\text { pensions }\end{array}$ & $\begin{array}{l}\text { ADJUSTED } \\
\text { total income }\end{array}$ & $\begin{array}{l}\text { ADJUSTED } \\
\text { Total as \% } \\
\text { Personal } \\
\text { sector gross } \\
\text { income }\end{array}$ & $\begin{array}{l}\text { ADJUSTED } \\
\text { Total as \% } \\
\text { (Personal } \\
\text { sector gross } \\
\text { income - } \\
\text { Transfers) }\end{array}$ \\
\hline 1908 & 824 & & 88 & 715 & 73 & 152 & $5 c$ & & 1682 & 94.02 & 94.33 \\
\hline 1909 & 822 & & 89 & 721 & 74 & 154 & $5 c$ & & 1689 & 92.56 & 93.28 \\
\hline 1910 & 838 & & 87 & 753 & 77 & 162 & $5 c$ & & 1747 & 91.94 & 92.68 \\
\hline 1911 & 866 & & 86 & 781 & 80 & 174 & 50 & & 1817 & 91.88 & 92.63 \\
\hline 1912 & 907 & & 84 & 811 & 84 & 180 & 50 & & 1899 & 91.74 & 92.63 \\
\hline 1913 & 951 & $\varepsilon$ & 90 & 835 & 89 & 180 & 50 & & 1966 & 91.63 & 92.63 \\
\hline 1914 & 985 & $\varepsilon$ & 95 & 830 & 95 & 176 & 50 & & 1990 & 89.22 & 90.36 \\
\hline 1915 & 1,050 & 23 & 103 & 910 & 99 & 227 & 50 & & 2164 & 80.91 & 81.74 \\
\hline 1916 & 1,373 & 34 & 113 & 1,040 & 61 & 158 & $5 c$ & & 2483 & 75.54 & 76.19 \\
\hline 1917 & 1,631 & 58 & 137 & 1,310 & 70 & 181 & $5 c$ & & 2982 & 75.03 & 75.96 \\
\hline 1918 & 2,072 & 145 & 170 & 1,640 & 83 & 198 & $5 c$ & & 3646 & 77.77 & 79.07 \\
\hline 1919 & 2,547 & 826 & 200 & 1,970 & 110 & 221 & 50 & & 3773 & 73.22 & 75.73 \\
\hline 1920 & 2,661 & 674 & 223 & 2,475 & 96 & 82 & 50 & & 4343 & 82.13 & 84.88 \\
\hline 1921 & 2,462 & 490 & 240 & 1,933 & 85 & 67 & 50 & & 3770 & 82.13 & 85.99 \\
\hline 1922 & 2,318 & 357 & 188 & 1,585 & 78 & 68 & 50 & & 3474 & 84.29 & 88.47 \\
\hline 1923 & 2,303 & 301 & 195 & 1,510 & 76 & 66 & 50 & & 3434 & 85.64 & 89.59 \\
\hline 1924 & 2,401 & 343 & 178 & 1,554 & 78 & 68 & 50 & & 3553 & 85.87 & 89.65 \\
\hline 1925 & 2,337 & 243 & 226 & 1,579 & 101 & 89 & 77 & & 3635 & 85.70 & 89.52 \\
\hline 1926 & 2,337 & 196 & 215 & 1,481 & 106 & 101 & 80 & 8 & 3628 & 86.54 & 90.94 \\
\hline 1927 & 2,416 & 285 & 209 & 1,624 & 104 & 101 & 80 & 11 & 3761 & 86.16 & 90.21 \\
\hline
\end{tabular}




\begin{tabular}{|c|c|c|c|c|c|c|c|c|c|c|c|}
\hline 1928 & 2,494 & 285 & 201 & 1,607 & 107 & 101 & 80 & 23 & 3846 & 87.24 & 91.41 \\
\hline 1929 & 2,531 & 290 & 217 & 1,638 & 106 & 103 & 80 & 26 & 3896 & 86.99 & 91.25 \\
\hline 1930 & 2,497 & 269 & 219 & 1,579 & 106 & 103 & 80 & 34 & 3833 & 86.60 & 91.54 \\
\hline 1931 & 2,826 & 620 & 167 & 1,495 & 49 & 66 & 80 & 39 & 3694 & 86.75 & 92.91 \\
\hline 1932 & 2,667 & 600 & 100 & 1,470 & 54 & 66 & 70 & 40 & 3594 & 86.16 & 92.40 \\
\hline 1933 & 2,621 & 620 & 83 & 1,497 & 66 & 66 & 70 & 42 & 3584 & 84.94 & 90.79 \\
\hline 1934 & 2,747 & 650 & 103 & 1,568 & 68 & 66 & 70 & 43 & 3731 & 86.36 & 92.07 \\
\hline 1935 & 2,839 & 680 & 178 & 1,624 & 72 & 70 & 70 & 44 & 3780 & 84.13 & 89.58 \\
\hline 1936 & 3,015 & 725 & 216 & 1,724 & 76 & 74 & 79 & 44 & 3984 & 84.23 & 89.25 \\
\hline 1937 & 3,231 & 785 & 232 & 1,842 & 79 & 70 & 85 & 45 & 4243 & 86.43 & 91.34 \\
\hline 1938 & 3,341 & 804 & 291 & 1,888 & 81 & 68 & 84 & 46 & 4320 & 85.65 & 90.69 \\
\hline 1939 & 3,425 & 908 & 290 & 2,010 & 86 & 77 & 84 & 53 & 4436 & 85.10 & 89.69 \\
\hline 1940 & 4,056 & 1,382 & 290 & 2,270 & 82 & 83 & 84 & 60 & 4849 & 82.53 & 86.49 \\
\hline 1941 & 4,846 & 1,911 & 290 & 2,560 & 71 & 82 & 84 & 67 & 5382 & 75.74 & 78.89 \\
\hline 1942 & 5,625 & 2,286 & 290 & 2,810 & 74 & 88 & 84 & 74 & 6038 & 76.90 & 79.99 \\
\hline 1943 & 5,912 & 2,365 & 290 & 2,940 & 79 & 90 & 84 & 81 & 6384 & 75.98 & 79.09 \\
\hline 1944 & 6,198 & 2,479 & 290 & 2,950 & 84 & 91 & 84 & 88 & 6579 & 76.28 & 79.61 \\
\hline
\end{tabular}




\section{List of Tables and Figures}

Table 1 Comparison of Income Tax Data Sources

Table 2NL NL Shares in Total Before Tax Income 1913-1999

Table 2UK UK Shares in Total Before Tax Income 1908-1999

Table 3NL NL Shares in Disposable Income 1959-1999

Table 3UK UK Shares in Total After Tax Income 1937-1999

Table A1 Sources of NL Data on Total Income

Table A2 Sources of NL Data on Disposable Income

Table B1 Sources for UK Super-Tax and Surtax Data

Table B2 Sources of UK SPI Data

Table C1 Netherlands Population Totals (thousands)

Table C2 Reference Income Totals in Netherlands (million guilders)

Table D1 Derivation of Control Totals ( $£$ million) for Income in UK applied to tax year data 1945/6-1999/2000

Table D2 Derivation of Control Totals ( $£$ million) for Income in UK 1907-1944

Figure $1 \quad$ Years for which data in NL and UK

Figure 2A Shares of Top $10 \%, 5 \%$ and $1 \%$

Figure 2B Shares of Top $0.5 \%, 0.1 \%$ and $0.05 \%$

Figure $3 \mathrm{~A} \quad$ Shares within Shares: Top $1 \%$ within $10 \%$, and top $0.1 \%$ within $1 \%$

Figure 3B Pareto Lorenz Coefficients (same groups)

Figure 4A Shares in After Tax Income of Top 10\%, 5\% and 1\%

Figure 4B Shares in After Tax Income of Top 0.5\%, $0.1 \%$ and $0.05 \%$

Figure 4C Shares within Shares After Tax

Figure $5 \quad$ Ratio of After Tax and Before Tax Shares

Figure C1 Tax Units in NL

Figure D1 Comparison of Control Totals as \% Personal Income in National Accounts 


\section{References}

Atkinson, A B, 2002, "Top Incomes in the United Kingdom over the Twentieth Century", Discussion Paper in Economic and Social History, No 43, University of Oxford.

Atkinson, A B and Harrison, A J, 1978, Distribution of Personal Wealth in Britain, Cambridge University Press, Cambridge.

Barna, T, 1945, Redistribution of Incomes Through Public Finance in 1937, Clarendon Press, Oxford.

Bowley, A L, 1914, "The British Super-Tax and the Distribution of Income", Quarterly Journal of Economics, vol 28: 255-268.

Bowley, A L, 1919, The Division of the Product of Industry, Oxford University Press, Oxford.

Bowley, A L, 1920, The Change in the Distribution of National Income, 1880-1913, Oxford University Press, Oxford.

Bowley, A L, 1930, Some Economic Consequences of the Great War, Butterworth, London.

Bowley, A L, 1937, Wages and Income in the United Kingdom since 1860, Cambridge University Press, Cambridge.

Bowley, A L, 1942, Studies in the National Income 1924-1938, Cambridge University Press, Cambridge.

Bowley, A L, and Stamp, J C, 1927, The National Income 1924, Oxford University Press, Oxford.

Cannan, E, Bowley A L, Edgeworth, F Y, Lees Smith, H B, and Scott, W R, 1910, "The Amount and Distribution of Income (other than Wages) Below the Income Tax Exemption Limit in the United Kingdom", Journal of the Royal Statistical Society, vol 74(1): 37-66.

Central Bureau of Statistics (CBS), 1961, National Accounts of the Netherlands 1960, Statistical Studies No 11, de Haan, Zeist.

Clark, C, 1932, The National Income 1924-1931, Macmillan, London.

Clark, C, 1934, "Further Data on the National Income", Economic Journal, vol 44: 380-397.

Clark, C, 1937, National Income and Outlay, Macmillan, London.

CBS (Centraal Bureau voor de Statistiek, Netherlands Central Bureau of Statistics), 1941, Berekeningen over het nationale inkomen van Nederland voor de periode 1900-1920, specialse onderzoekingen van de Nederlandse conjunctuur, no 4.

CBS, 1948, Het nationale inkomen van Nederland, 1921-1939, Monografieen van de nederlandse conjunctuur, deel 8, W. de Haan, Utrecht. 
CBS, 1949, "National Accounts of the Netherlands 1946 and 1947”, Special Statistical Communications, No 4001, The Hague.

CBS, 1950, "Het nationale inkomen van Nederland, 1940-1945", Statistische en econometrische onderzoekingen, vol. 5 no 1, 31-45

CBS, 1961, "National accounts of the Netherlands 1960", Statistical Studies, No 11, W de haan, Zeist.

CBS, 1973, nationale rekeningen 1972, staatsuitgeverij, s'Gravenhage.

CBS, 1975, nationale rekeningen 1974, staatsuitgeverij, s'Gravenhage.

CBS, 1982, nationale rekeningen 1981, staatsuitgeverij, s'Gravenhage.

CBS, 1996, National accounts of the Netherlands 1995, Sdu Publishers, The Hague.

CBS, 1998, National accounts of the Netherlands 1997, Sdu Publishers, The Hague.

Central Planning Bureau, 1999, Macroeconomische Verkenning 2000, The Hague

Central Statistical Office, various years, National Income and Expenditure, HMSO, London.

Champernowne, D G, 1936, The Distribution of Income between Persons, Prize Fellowship dissertation, King's College, Cambridge.

Champernowne, D G, 1973, The Distribution of Income between Persons, Cambridge University Press, Cambridge.

Colwyn Committee, 1927, Report of the Committee on National Debt and Taxation, Cmd.2800, HMSO, London.

Cowell, F A, 1995, Measuring Inequality, second edition, Prentice Hall, London.

Crosland, C A R, 1964, The Future of Socialism, second edition, Jonathan Cape, London.

Feenberg, D R and Poterba, J M, 1993, "Income Inequality and the Incomes of Very High-Income Taxpayers: Evidence from Tax Returns", in Poterba, J, editor, Tax Policy and the Economy, vol. 7, MIT Press, Cambridge, 145-177.

Feenberg, D R and Poterba, J M, 2000, "The Income and Tax Share of Very High-Income Households, 1960-1995”, American Economic Review, Papers and Proceedings, vol. 90: 264270.

Feinstein, C H, 1972, Statistical Tables of National Income, Expenditure and Output of the U.K. 1855-1965, Cambridge University Press, Cambridge.

Gastwirth, J L, 1972, “The Estimation of the Lorenz Curve and Gini Index”, Review of Economics 
and Statistics, vol. 54: 306-316.

Hartog, J, 1983, "Inequality reduction by income taxes: Just how much? An investigation for the Netherlands, 1914-1973", Empirical Economics, vol 8: 9-13.

Hartog, J and Veenbergen, J G, 1978, "Long-Run Changes in Personal Income Distribution", De Economist, vol 126: 521-549.

House of Commons, 1906, Report of the Committee on Income Tax, No 365, HMSO, London.

Inland Revenue, various years, Annual Reports of the Commissioners, HMSO, London.

Inland Revenue, 1983, The Survey of Personal Incomes 1979-80, HMSO, London.

Kleijn, J P de, and Stadt, H van der, 1987, Inkomensniveau en inkomensongelijkheid 1959-1984, Supplement bij de Sociaal-Economische Maandstatistiek 1987 no 6, 11-38

Kraus, F, 1981, "The Historical Development of Income Inequality in Western Europe and the United States", in P. Flora and A. J. Heidenheimer (eds.), The Development of Welfare States in Europe and America, Transaction Books, New Brunswick, N.J.

Kuznets, S, 1953, Shares of Upper Income Groups in Income and Savings, National Bureau of Economic Research, New York.

Lydall, H F, 1959, "The Long-Term Trend in the Size Distribution of Income", Journal of the Royal Statistical Society, Series A, vol 122: 1-46.

Macgregor, D H, 1936, “Pareto’s Law”, Economic Journal, vol 46: 80-87.

Minister of Reconstruction, 1944, “Social Insurance, Part I”, Cmd 6550, HMSO, London.

Morrisson, C, 2000, "Historical Perspectives on Income Distribution: The Case of Europe", in Handbook of Income Distribution, ed Atkinson, A B and Bourguignon, F, Elsevier, Amsterdam.

Nierop, C and Salverda, W, 2003, “Top-Income Shares in the Netherlands 1977-1999”, Amsterdam Instituut voor ArbeidsStudies, Universiteit van Amsterdam, mimeo.

Pen, J, 1979, "A Clear Case of Leveling: Income Equalization in the Netherlands", Social Research, vol 46: 682-694.

Piketty , T, 1998, "Les hauts revenus face aux modifications des taux marginaux supérieurs de l'impot sur le revenu en France, 1970-1996", Discussion Paper 9812, CEPREMAP, Paris.

Piketty, T, 2000, Les hauts revenus en France au $20^{\text {ème }}$ siècle, forthcoming.

Piketty , T, 2000a, "Income Inequality in France, 1901-1998", draft, CEPREMAP, Paris.

Piketty, T, and Saez, E, 2001, Income Inequality in the United States, 1913-1998, NBER Working Paper $n^{\circ} 8467$ 
Pott-Buter, H A, and Tijdens, K G, 2002, Emancipatie-effectrapportage belasting en premies, een verkenning naar nieuwe mogelijkheden vanuit het belastingstelsel 2001, AIAS Research Report 12, Amsterdam Institute for Advanced Labour Studies, Universiteit van Amsterdam

Ramprakash, D, 1975, "Distribution of Income Statistics for the United Kingdom, 1972/73: Sources and Methods", Economic Trends, 262: 78-96.

Royal Commission on the Distribution of Income and Wealth, 1975, Report No.1, Initial Report on the Standing Reference, Cmnd. 6171, HMSO, London.

Royal Commission on the Distribution of Income and Wealth, 1976, Report No.3, Higher Incomes from Employment, Cmnd. 6383, HMSO, London.

Royal Commission on the Distribution of Income and Wealth, 1979, Report No.7, Fourth Report on the Standing Reference, Cmnd. 7595, HMSO, London.

Royal Commission on the Income Tax, 1920, Report, Cmd. 615, HMSO, London.

Royal Commission on the Income Tax, 1920a, Index to the Evidence and Appendices, Cmd. 288, HMSO, London.

Saez, E and Veall, M, 2003, "The Evolution of High Incomes in Canada, 1920-2000”, NBER Discussion Paper.

Sørensen, R S, 1993, "Changes in the Personal Income Distribution 1870-1986" in The Economic Development of Denmark and Norway since 1870, Edward Elgar, Cheltenham.

Schultz, T P, 1968, "Secular Equalization and Cyclical Behavior of Income Distribution", Review of Economics and Statistics, vol 50: 259-267.

Stamp, J C (Lord), 1914, "A New Illustration of Pareto's Law", Journal of the Royal Statistical Society, vol 77: 200-204.

Stamp, J C (Lord), 1916, British Incomes and Property, P S King, London.

Stamp, J C (Lord), 1936, "The Influence of the Price Level on the Higher Incomes", Journal of the Royal Statistical Society, vol 99: 627-673.

Stark, T, 1972, The Distribution of Personal Income in the United Kingdom 1949-1963, Cambridge University Press, Cambridge.

Stark, T, 1978, "Personal Incomes" in W.F. Maunder, editor, Reviews of United Kingdom Statistical Sources, Volume 6, Pergamon Press, Oxford.

Szirmai, A, 1986, Inequality Observed, Avebury, Aldershot.

Titmuss, R M, 1962, Income Distribution and Social Change, Allen and Unwin, London. 
United Nations, 1983, Yearbook of National Accounts 1981, United Nations, New York. 
Figure 1 Years for which data in NL and UK

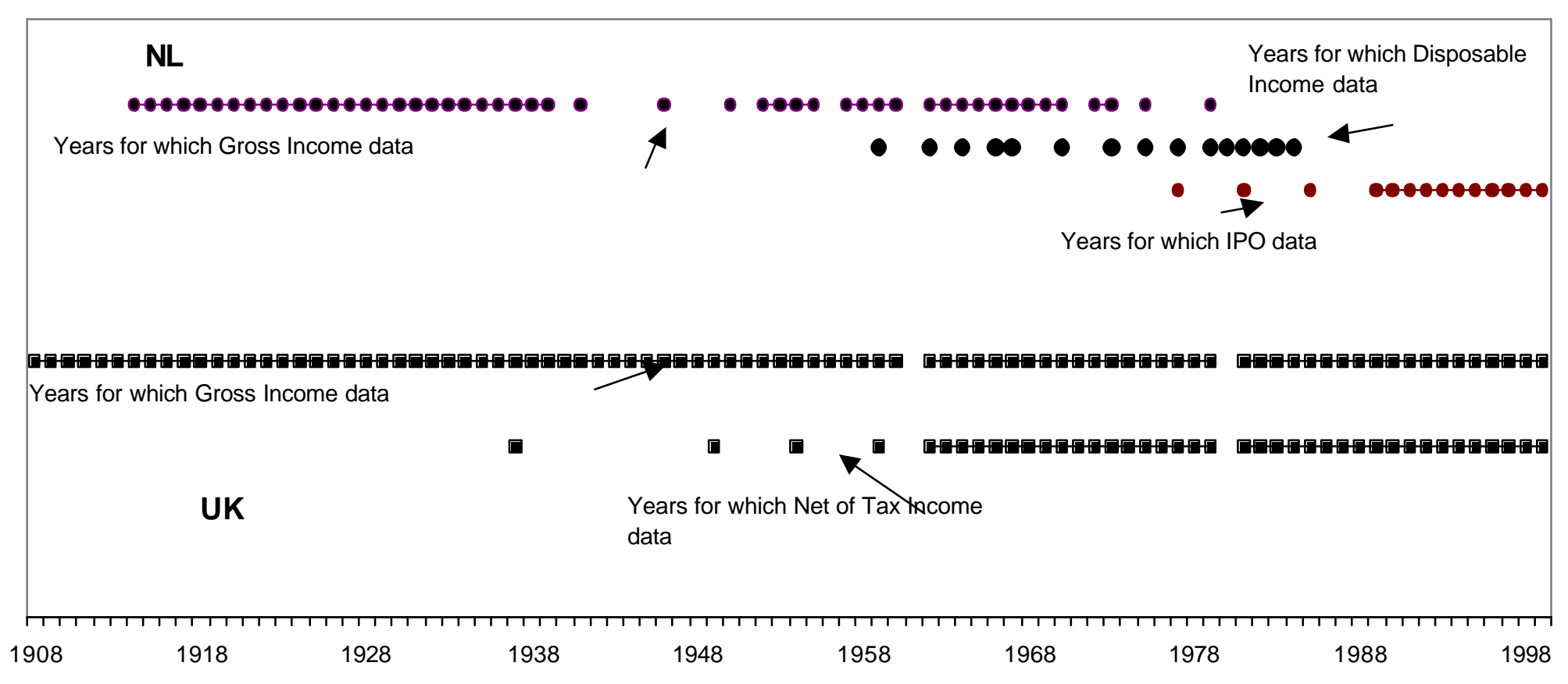


Figure $2 A$ Shares of Top $10 \%, 5 \%$ and $1 \%$

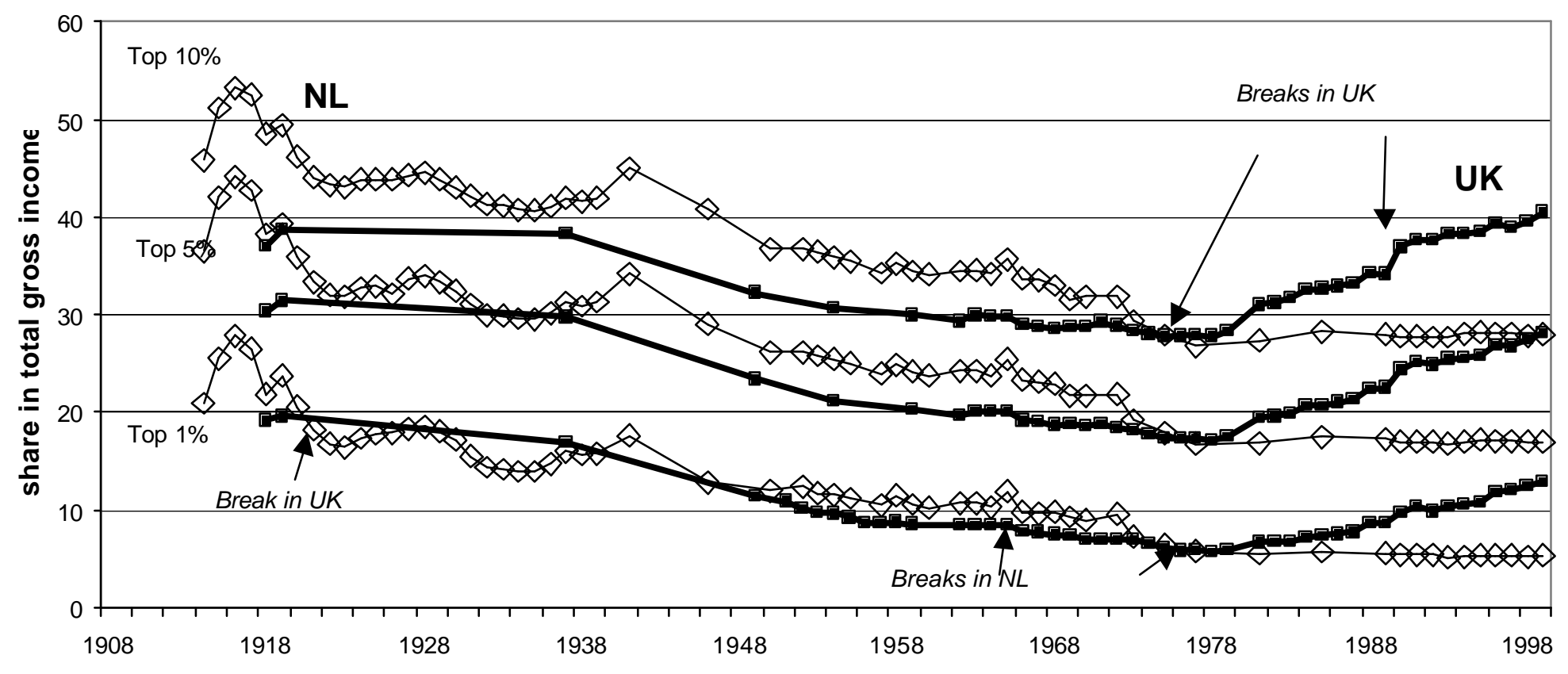


Figure 2B Shares of Top $0.5 \%, 0.1 \%$ and $0.05 \%$

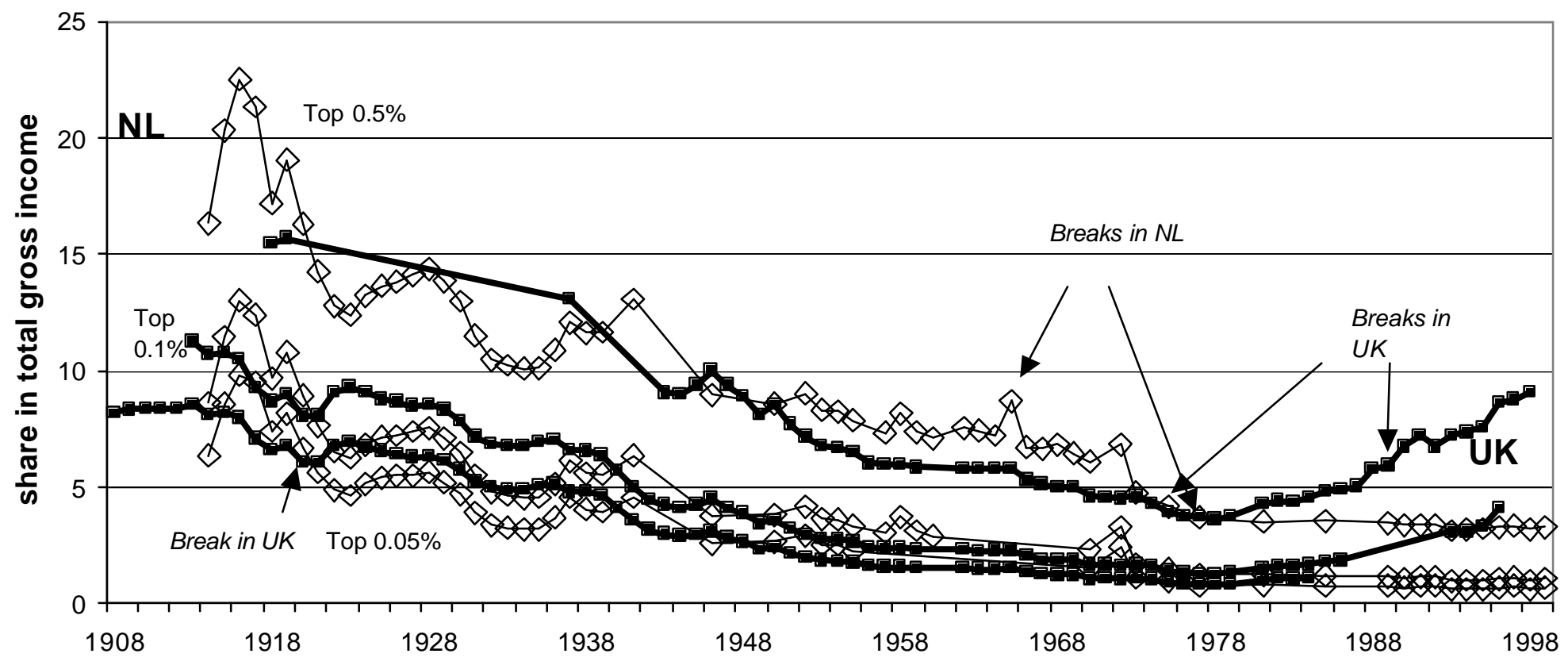




\section{Figure 3A Shares within Shares}

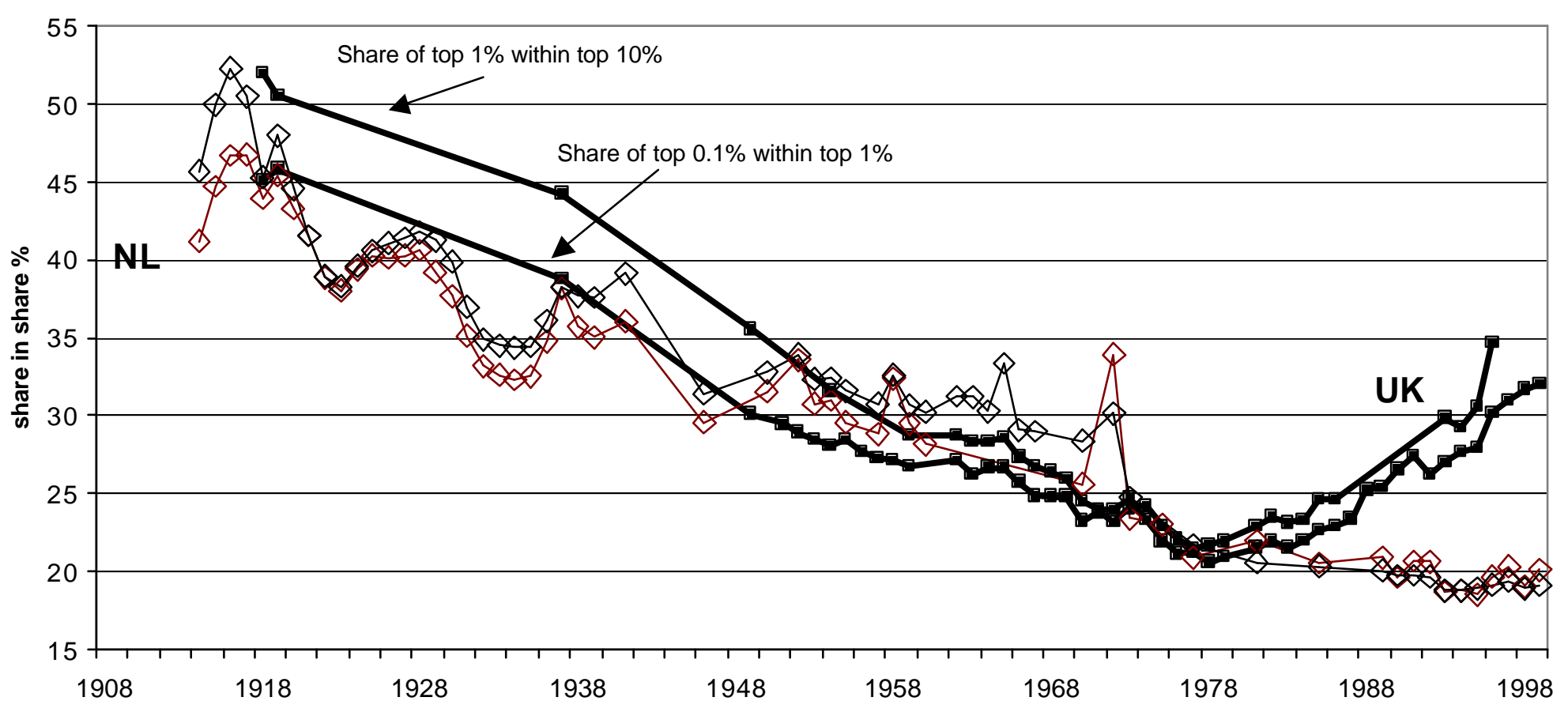


Figure 3B Pareto Lorenz Coefficients

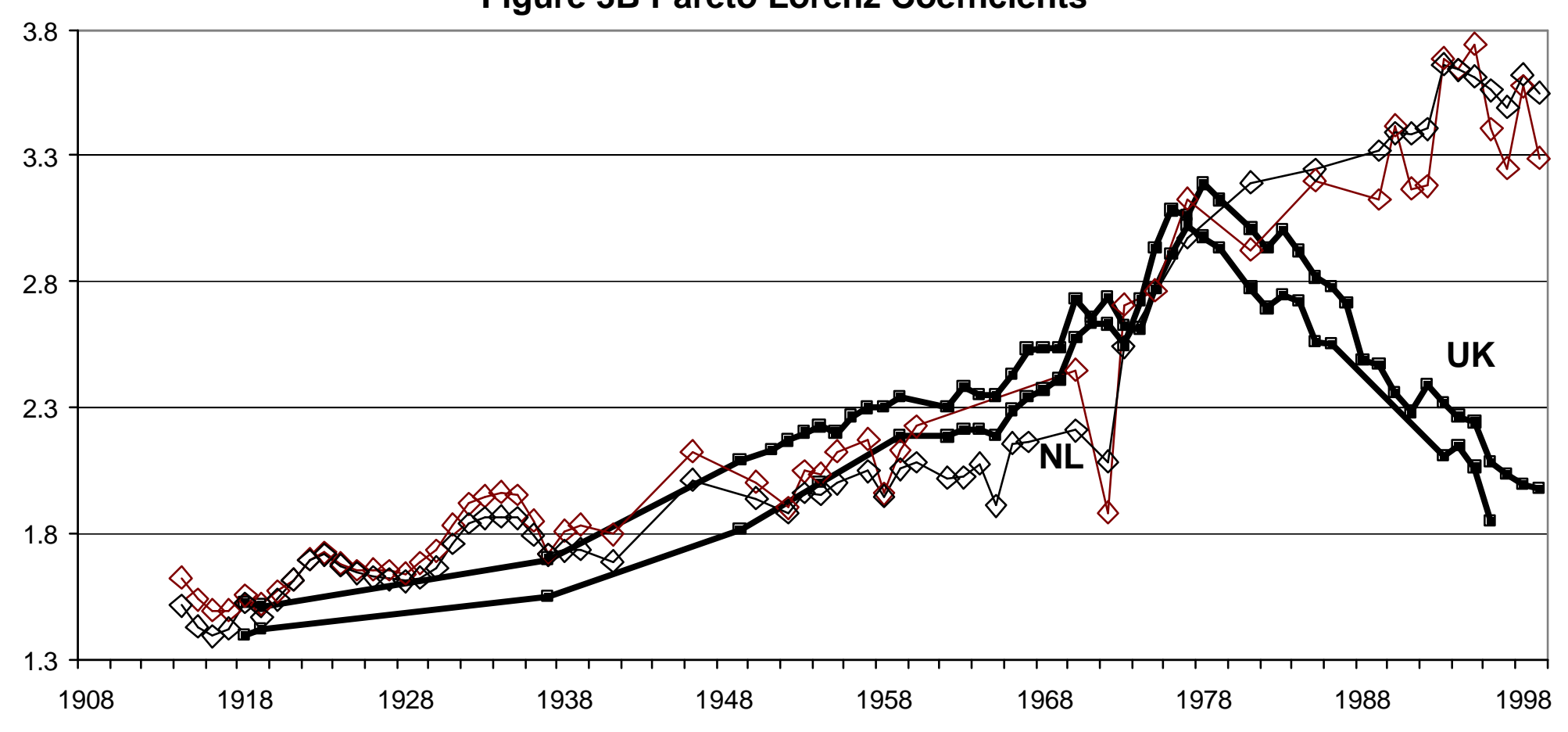


Figure 4A Shares in After Tax Income of Top 10\%, 5\% and 1\%

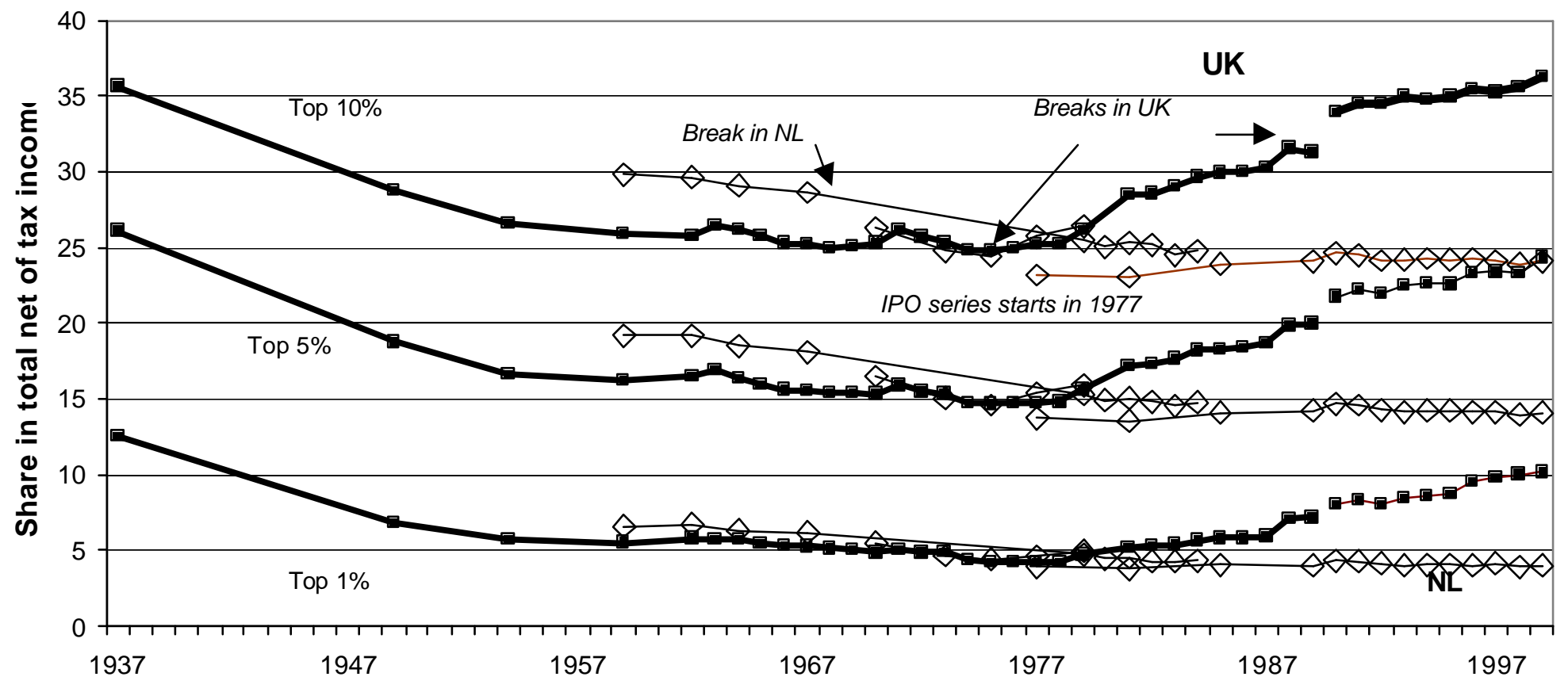


Figure 4B Shares in After Tax/Disposable Income of Top $0.5 \%$ and $0.1 \%$

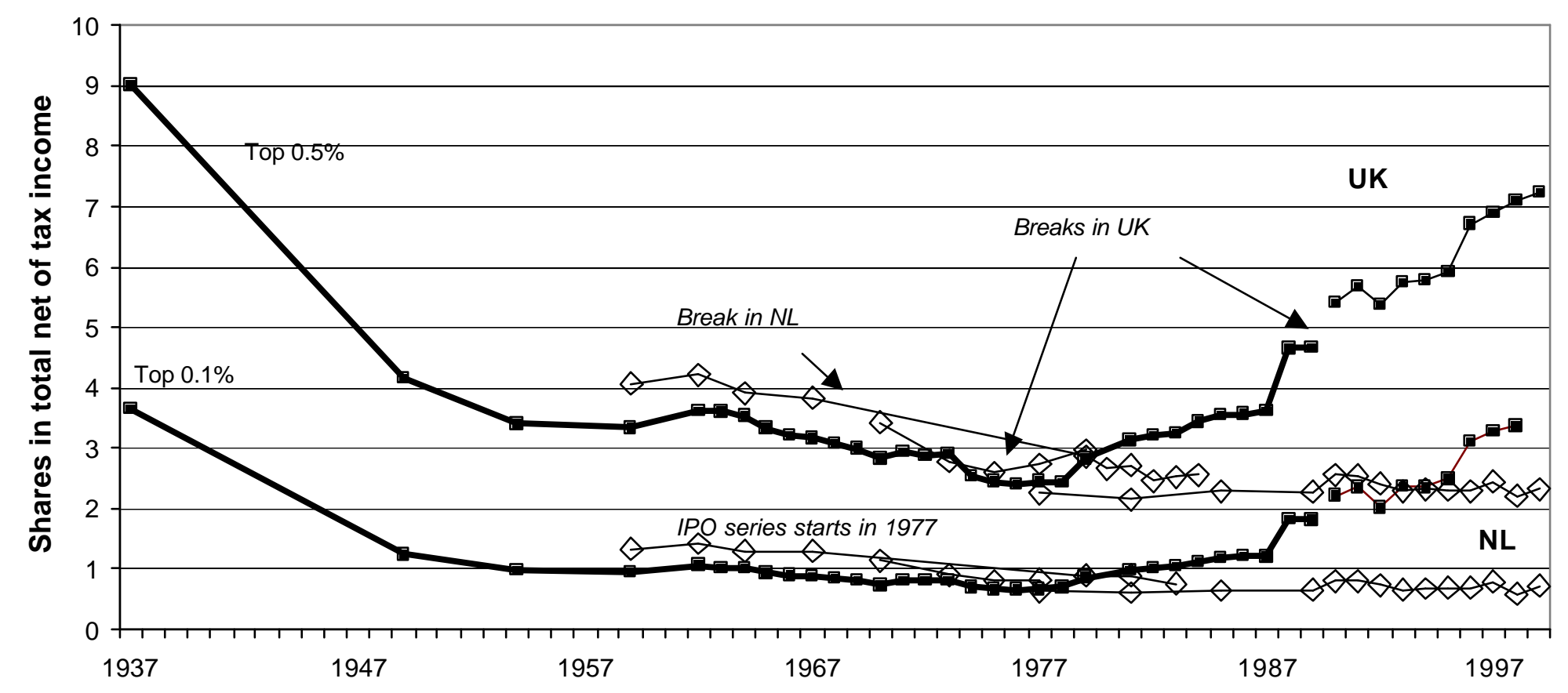




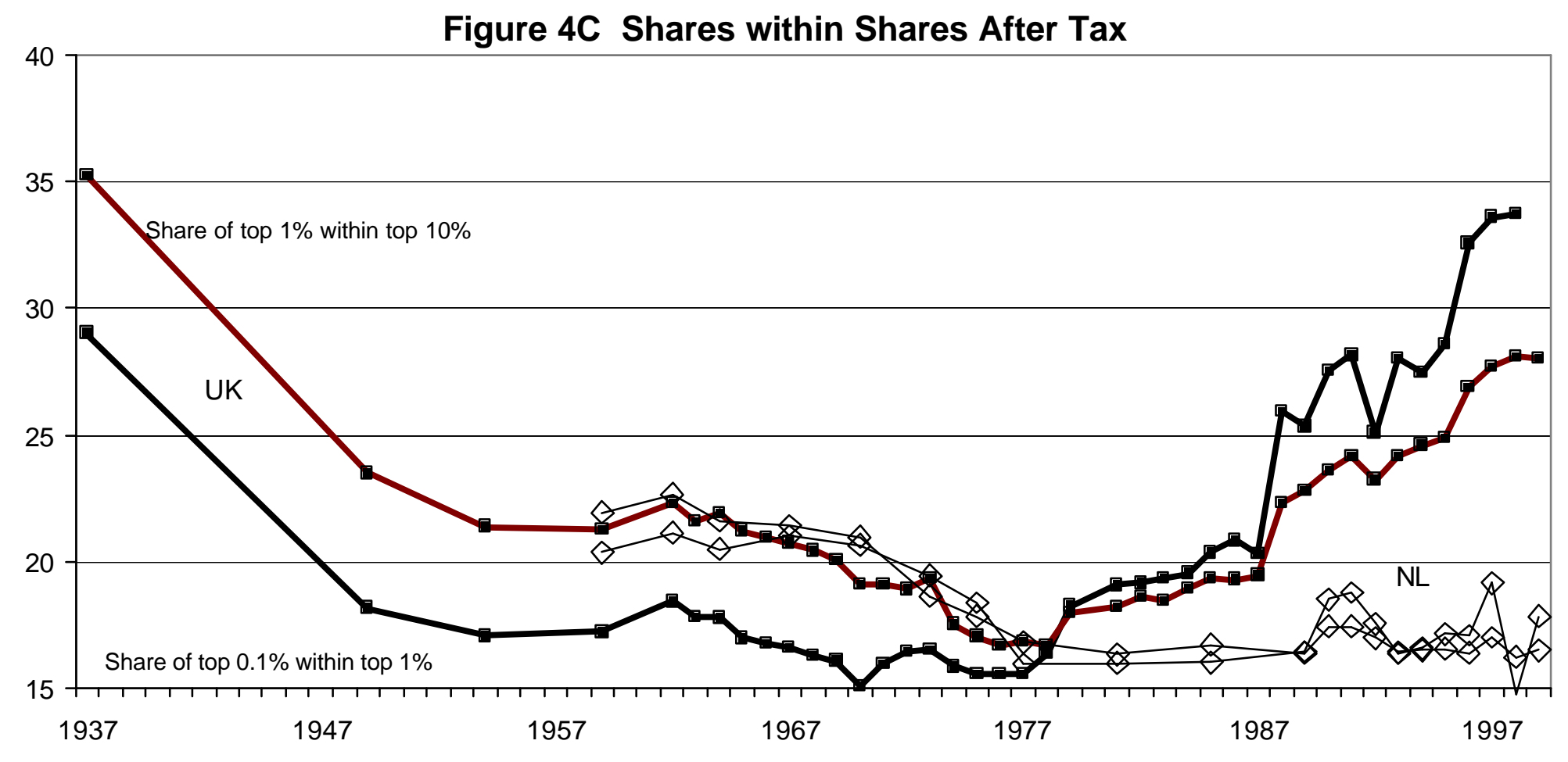


Figure 5 Ratio of After Tax and Before Tax Shares

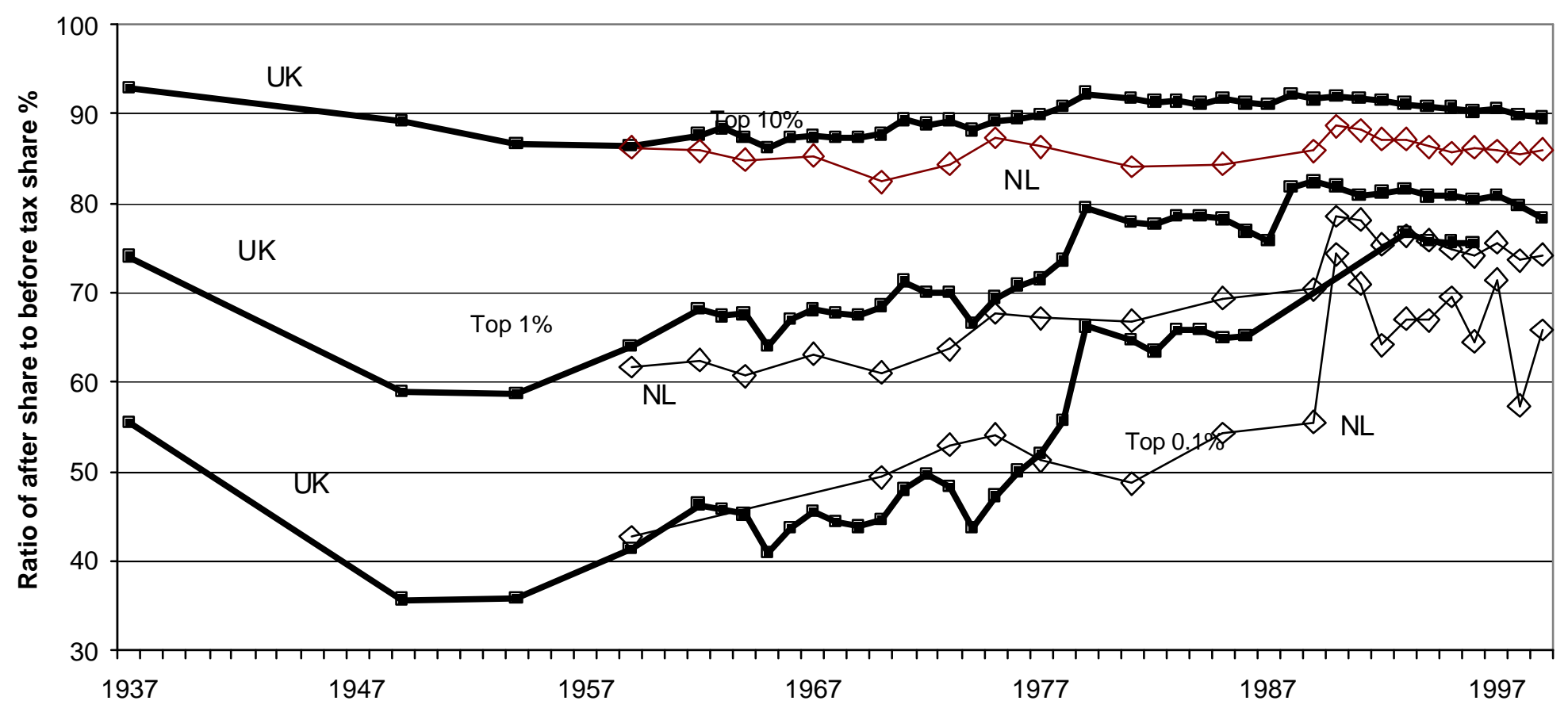




\section{Figure C1 Tax Units in NL}

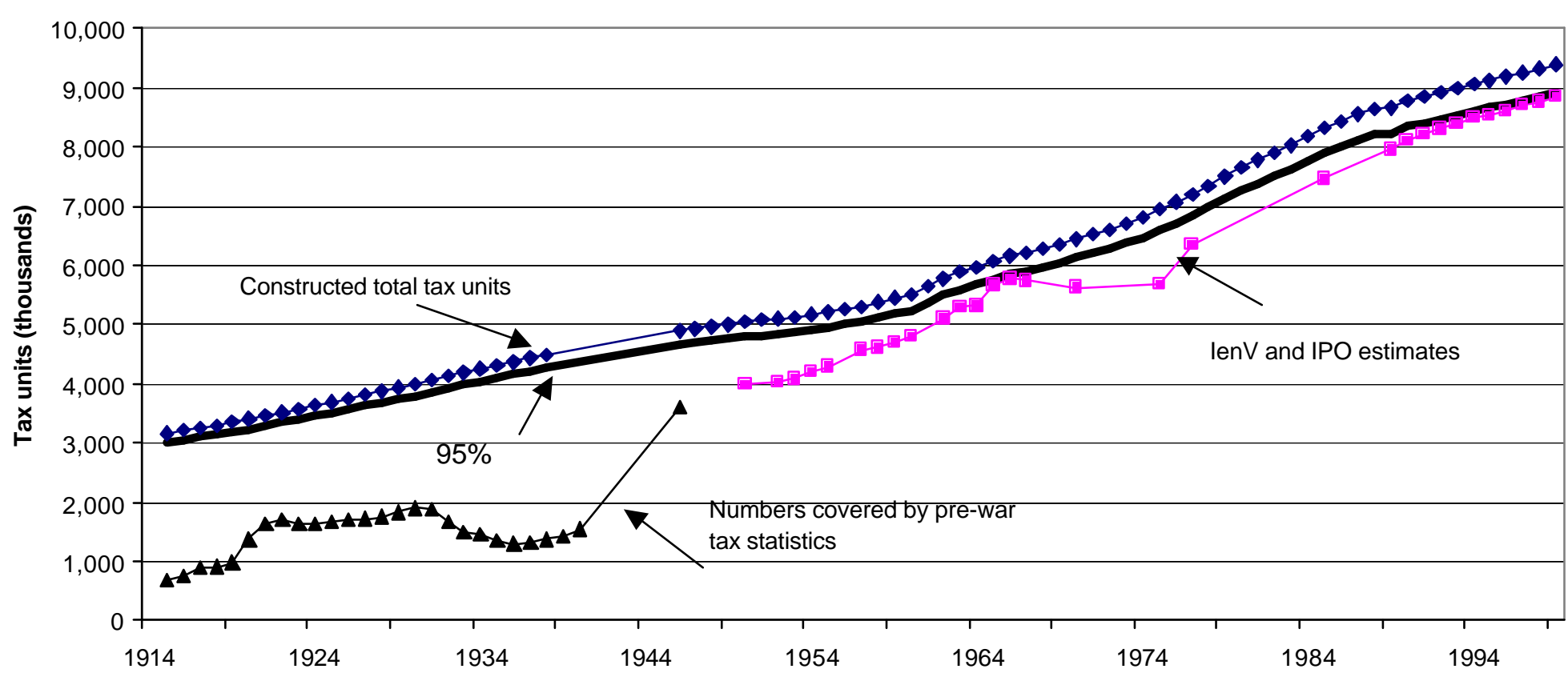


Figure D1 Comparison of Control Totals as \% Personal Income in National Accounts

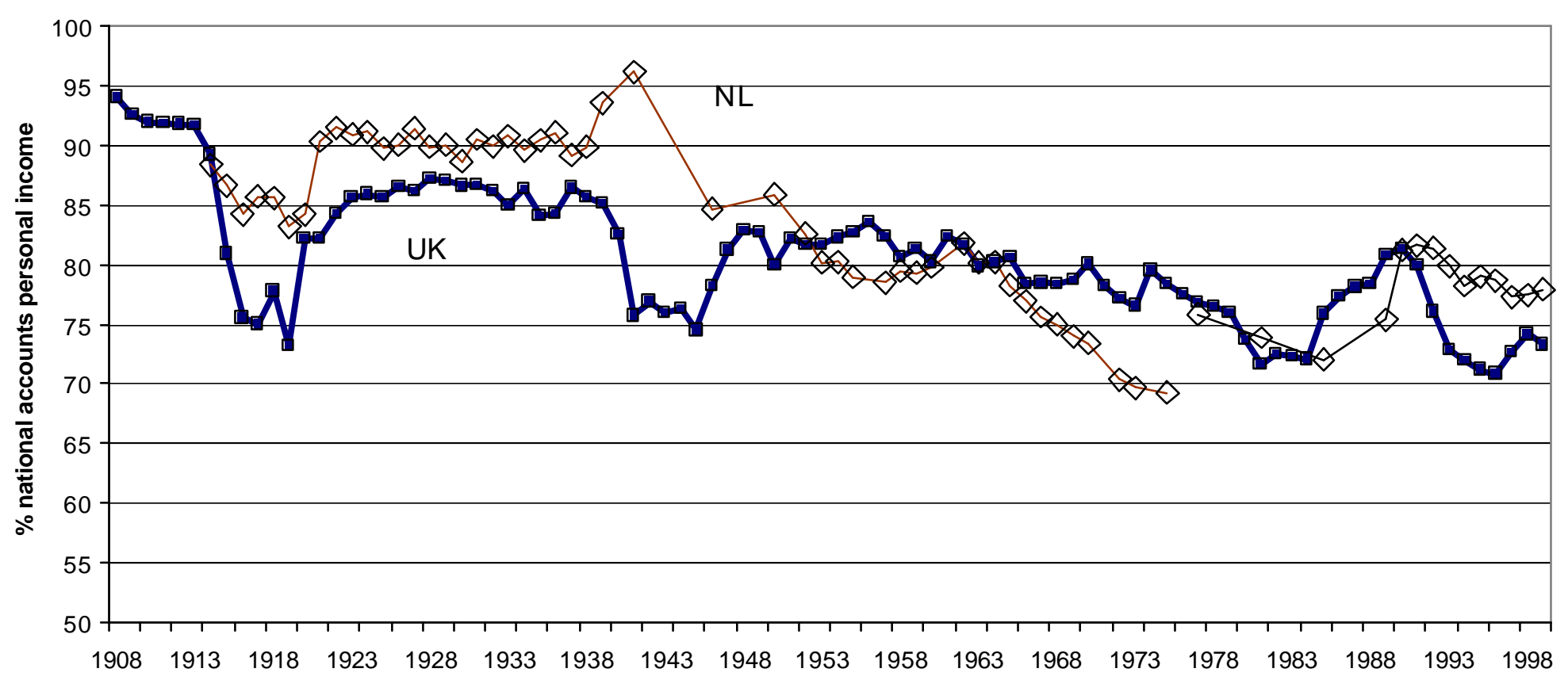

